Digital Comprehensive Summaries of Uppsala Dissertations from the Faculty of Science and Technology 2050

\title{
The effects of exposure to microplastics and pollutants on the arthropod microbiome
}

JAVIER EDO VARG

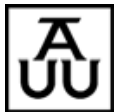

ACTA UNIVERSITATIS UPSALIENSIS UPPSALA
ISSN 1651-6214

ISBN 978-91-513-1224-8

URN urn:nbn:se:uu:diva-442173 
Dissertation presented at Uppsala University to be publicly examined in Zootissalen, Evolutionary Biology Centre, Villavägen 9, Uppsala, Friday, 22 October 2021 at 10:00 for the degree of Doctor of Philosophy. The examination will be conducted in English. Faculty examiner: Professor Jarone Pinhassi (Linnéuniversitetet, Kalmar).

Online defence: https://uu-se.zoom.us/j/65146680565

\begin{abstract}
Varg, J. E. 2021. The effects of exposure to microplastics and pollutants on the arthropod microbiome. Digital Comprehensive Summaries of Uppsala Dissertations from the Faculty of Science and Technology 2050. 41 pp. Uppsala: Acta Universitatis Upsaliensis. ISBN 978-91-513-1224-8.
\end{abstract}

Anthropogenic pollution is widespread across various ecosystems. This disturbance can alter the interaction between a host and its associated microbiome, with repercussions for hosts traits such as health, behavior, and host evolution. The thesis aim is to understand the effects of inert microplastics and other pollutants, as pesticides, detergents, and toxic metals, on the host-microbiota of different freshwater invertebrates. Specifically, this thesis explores the secondary effects of stress factors on the host, trophic interactions, and free-living microbes. Chapter I tested the effects of microplastics and the pesticide esfenvalerate on Chironomus riparius survival, emergence, and its microbiome. Chapter II tested the effects of microplastics and the pesticide deltamethrin on a trophic chain of three organisms: Daphnia magna, damselfly larva Ischnura elegans, and wild dragonfly larva Aeshna cyanea. Chapter III tested the effects of microplastics and sodium dodecyl sulfate on the microbiome of wild water boatman from the family Corixidae. Chapter IV tested the effects of microplastics and Chromium VI on Daphnia magna mortality and its microbiome. The thesis used metagenomic tools to characterize both the host microbiome and its surrounding microcosms. Our results showed that microplastics interact with additive toxicants to affect the host microbiome, however, these effects depend on the type of toxicant, the size of the microplastic, and the host itself.

Keywords: ecotoxicology, host microbiota, freshwater, anthropogenic pollution, microplastics, pesticides, pyrethroids, detergents, toxic metals, daphnids, chironomids, water boatmen, damselflies, dragonflies

Javier Edo Varg, Department of Ecology and Genetics, Animal ecology, Norbyvägen 18 D, Uppsala University, SE-752 36 Uppsala, Sweden.

(C) Javier Edo Varg 2021

ISSN 1651-6214

ISBN 978-91-513-1224-8

URN urn:nbn:se:uu:diva-442173 (http://urn.kb.se/resolve?urn=urn:nbn:se:uu:diva-442173) 
To my Demons 



\section{List of Papers}

This thesis is based on the following papers, which are referred to in the text by their Roman numerals.

I Varg, E, J., Kunce, W., Outomuro, D., Svanbäck. R., Johansson, F. (2021). Single and combined effects of microplastics, pyrethroid and food resources on the life-history traits and microbiome of Chironomus riparius. Manuscript

II Varg, E, J., Outomuro, D., Kunce, W., Kuehrer, L., Svanbäck. R., Johansson, F. (2021). Microplastic exposure across trophic levels: effects on the host microbiota of freshwater organisms. Manuscript

III Varg, E, J \& Svanbäck. R. (2021). Multi stress system: microplastics in freshwater and their effects in host microbiota. Manuscript

IV Varg, E, J \& Svanbäck. R. (2021). The stressful effects of microplastics associated with chromium (VI) on the microbiota of Daphnia Magna. Manuscript 



\section{Contents}

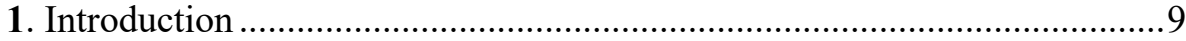

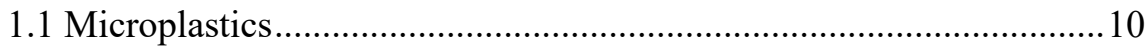

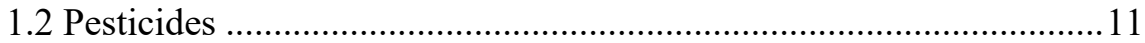

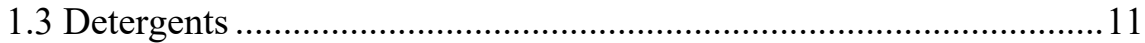

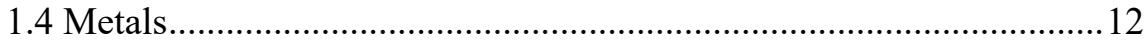

1.5 Aims of the thesis ........................................................................... 13

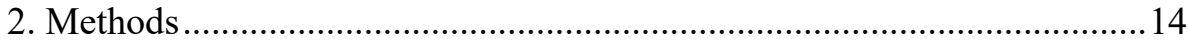

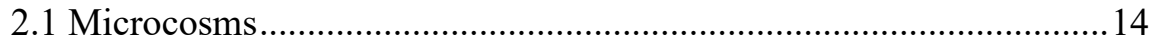

2.2 DNA extraction and library preparation ..........................................16

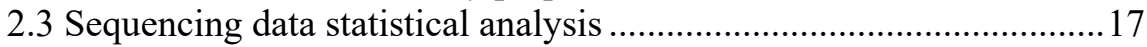

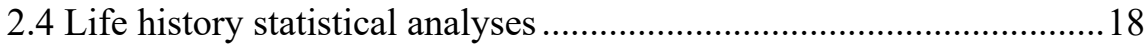

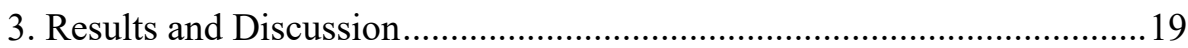

3.1 Effects of MPs alone on the host-microbiome...................................19

3.2 Effect of single toxicants in the host-microbiome ..............................21

3.3 Combined effects of MPs and toxicants on the host-microbiome......23

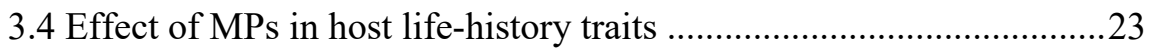

3.5 Effect of single toxicants in the host life-history traits .......................25

3.6 Combined effects of MPs and toxicants in host life-history traits......25

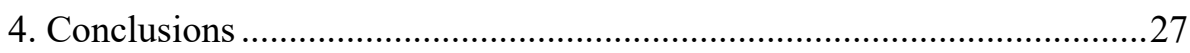

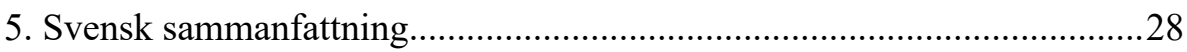

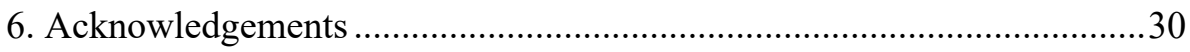

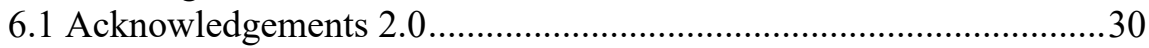

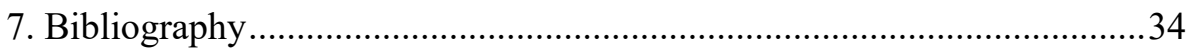




\section{Abbreviations}

MPs - Microplastics

DMT - Deltamethrin

Cr(VI) - Chromium (VI)

SDS - Sodium dodecyl sulfate

DNA - Deoxyribonucleic acid

RNA - Ribonucleic acid

PCR - Polymerase chain reaction

ASV - Amplicon sequence variant

PERMANOVA - Permutational Multivariate Analysis of Variance

PCoA - Principal Coordinates Analysis

MANOVA - Multivariate Analysis of Variance

GLM - Generalized Linear Model

GLMM - Generalized Linear Mixed Model

GLS - Generalized Least Squares fit model 


\section{Introduction}

The diversity of microorganisms and microbial communities are ubiquitous, and they are cornerstones for the evolution of life (Foster et al. 2017, Sharpton 2018). All the living assemblage of microorganisms (bacteria, archaea, fungi, algae, small protists), and all genetic content including mobile genetic elements such as viruses, plasmids, and transposons are known as the microbiome. The majority of microbes in the microbiome are essential for the ecosystem function and have coevolved with the macro-organisms they inhabit (Maynard et al. 2012, Stilling et al. 2014, Moran and Sloan 2015, Douglas 2016, Wasielewski et al. 2016, Richardson 2017, Gould et al. 2018, Berg et al. 2020). Macro-organisms hold an immense and diverse community of microbes in and on their bodies. This host-microbiome has been shown to play an important role in many aspects of the host's function; microbiome studies have a bacteriocentric view due to the very high functional bacterial diversity that inhabit the host (Cénit et al. 2014, Marchesi et al. 2015). These microorganisms are very important for physiological processes and lifehistory traits such as health, growth, and development of the host (Nicholson et al. 2012, Jin et al. 2018, Zha et al. 2018). Similarly, it is well known that the host-microbiome is a key dimension of biochemical processes of every single organism affecting nutrition, immunity maturation, pathogen resistance, and host behavior (Huttenhower et al. 2012, Hanning and DiazSanchez 2015, Roger et al. 2016, Foster et al. 2017).

Fitness components such as survival, fecundity, growth, development and lifespan are also affected by the microbial communities that inhabiting the host (Huttenhower et al. 2012, Tremaroli and Bäckhed 2012, McFall-Ngai et al. 2013, Sommer and Bäckhed 2013, Rosenberg and Zilber-Rosenberg 2014, Souza et al. 2019). For example, the results of Gould et al. (2018) suggest that microbial composition and the timing of the interaction can highly impact lifespan as well as life-history tradeoffs in the fruit fly Drosophila melanogaster. Several studies have reported effects in fitness and life-history traits in diverse host organisms as a result of changes in microbial composition (Seung Chul et al. 2011, Semova et al. 2013, Kohl et al. 2016, Butt and Volkoff 2019). The magnitudes of the interactions in the microbial structure can be a major driver of host physiology (Gould et al. 2018). However, the effects in life-history traits and microbiome can as well 
be due to factors such as diet (including the prey microbiome) and host genetics (Bolnick et al. 2014, Dehler et al. 2017, Gould et al. 2018).

\subsection{Microplastics}

Since microorganisms grow in relatively stable conditions and nutrients, both host-associated and free-living microorganisms can be affected by environmental stressors such as pollutants. Exposure to pollutants such as microplastics (MPs) can affect the host-microbiome (Jin et al. 2018, Lu et al. 2018, Zhu et al. 2018, Qiao et al. 2019). MPs are plastic debris $<1 \mathrm{~mm}$ with different shapes that include fragments of plastic items that undergo some kind of degradation: such as physical (wind, waves, and sand abrasion), chemical (salting and burial in sand rich in organic matter), photochemical and thermal (Costa et al. 2009, Browne et al. 2011, Cole et al. 2015a). Ingesting MPs instead of food can modify the host environment and its gut and provide a new carbon source in addition to providing a novel surface that only some microbes can colonize (Zettler et al. 2013, McCormick et al. 2014, Lu et al. 2018, Jacquin et al. 2019, Amaral-Zettler et al. 2020). Such changes in the microbial communities, known as dysbiosis, could end up in a loss of important functions for the host. For example, microbiota have a role on the host immune response, development and function of vital organs (e.g. the brain), and production of key elements, e.g. vitamin B12 (Kock and Schmid-Hempel 2011; Bennett et al 2015; Farmer et al 2014; Marchesi et al 2015). Thus, the presence of ingested MPs with novel bacterial gut or skin colonization might change the microbial community and subsequently alter host responses and host metabolisms.

The presence of more than 100000 microplastic particles per $\mathrm{m}^{3}$ of debris is considered to be an environmental problem (UNEP, 2005; Eerkes-Medrano et al 2015). In fact, a large variety of aquatic organisms have been reported to ingest and accumulate MPs, from zooplankton to fish (Mattsson et al 2015; Cole et al 2015). One of the major concerns about MPs is thus that they can enter food webs via direct ingestion because of their bioavailability in water environments and terrestrial ecosystems (Cole et al 2013; Tanaka 2013). However, there are also indirect ways to be exposed to MPs such as ingestion through predation on organisms that contain MPs. Hence, MPs can be transported in the food chain (Nowack et al 2007; Zhu et al 2008; Ferry et al 2009; Mattsson et al 2015).

The effects of microplastic ingestion can either be physical damage or toxic, depending on the material and whether the plastic is associated with a toxic chemical. This may compromise individual fitness by reducing feeding, energetic reserves, growth rate, fecundity, and survival (Cole et al 2016). 
Moreover, the bioavailability of MPs and their possible interactions with other pollutants such as toxic metals, pesticides, and normal household products such as detergents might be synergistic (Tanaka et al. 2013, Rochman et al. 2014, Wang et al. 2016, Wagner and Lambert 2018, Felten et al. 2020). The joint synergic effects of MPs and toxicants on organisms and their microbiome remain unexplored and constitutes one of the new frontiers in toxicology.

\subsection{Pesticides}

Pesticides are organic chemical compounds that are designed specifically to interfere the organismal biochemistry to kill or prevent the growth of undesired organism i.e. pest and pathogens (Bernhardt et al. 2017). Pyrethroid pesticides such as Deltamethrin (DMT) and esfenvalerate are known for their neurotoxic effects. Pyrethroids are extensively applied in agriculture, aquaculture, and forestry as pest control agents (Mestres and Mestres 1992, Hong et al. 2020), and they can enter the aquatic ecosystem via stormwater run-off from urban landscaping and home gardens as well as wastewater effluent and agricultural run-off (Jiang et al. 2010, Weston et al. 2013). DMT can negatively affect a variety of organisms including mammals and birds, but it is highly toxic to aquatic organisms such as fish and aquatic arthropods (Dawood et al. 2020, Hong et al. 2020). Esfenvalerate has also been shown to have negative effects on the survival and development on many aquatic invertebrates (Beketov 2004, Forbes and Cold 2005, Amweg et al. 2006, Brady et al. 2006, Rasmussen et al. 2013, Rodrigues et al. 2015). Pyrethroids to control pests acts mainly in the excitable membrane focusing on the voltage-gated $\mathrm{Na}^{+}$channel of the nervous system, including transduction signals (Mestres and Mestres 1992, Hong et al. 2020). Moreover, the effect of pyrethroids in non-target organisms might be heightened due to the presence of other stressors, nutritional deficiencies, or pollutants such as MPs (Menéndez-Pedriza and Jaumot 2020). Studies on the combination of both MPs and pyrethroids are scarce and do not take into account its effects on the microbial communities both in the environment and in the host (Zettler et al. 2013, Horton et al. 2018, Felten et al. 2020).

\subsection{Detergents}

Detergents are highly surface-active chemical compounds (i.e. surfactants) with a complex structure that are able to disorganize cell membranes and denature proteins (Baker et al. 1941, Sobrino-Figueroa 2018). The effects of detergents and their toxicity in aquatic organisms have been studied since 1950 (Czyzewska 1975), yet detergents continue to be used daily worldwide 
and released in aquatic environments. Prolonged exposure to detergents such as Sodium dodecyl sulfate (SDS) can induce paralysis, affect biological function, and end in the death of the organism (Czyzewska 1975, SobrinoFigueroa 2018, Gerasimidis et al. 2019). MPs and detergents can be manufactured together or can converge in water environments after disposition (Sibley and Hanson 2011). Though it is well known that detergents also function as bactericides (Baker et al. 1941, Brandt et al. 2001, Mousavi and Khodadoost 2019), we lack knowledge on how detergents can affect hostassociated microorganism as well as the possible interactions that detergents might have with MPs.

\subsection{Metals}

Metal ions are known to be highly toxic and can occur in food, water, or air (Tchounwou et al. 2012). Because of its toxicity, chromium is one of the toxic metal ions ranked as a priority with great public health significance (Tchounwou et al. 2012). Chromium, specifically the state VI (Cr(VI)), has been attributed to highly carcinogenic, nephrotoxic, hepatotoxic, neurotoxic, and mutagenic effects along with other pathophysiological effects (Zeng et al. 2016, Bojarski et al. 2021, Guo et al. 2021). Cr(VI) is the most toxic state of chromium and it is found in water environments because of several industrial processes such as leathering tanning, electroplating manufacturing of dye, metal finishing, and production of paint and paper (Pérez-Candela et al. 1995, Vargas and Dussán 2016, Guo et al. 2021). Cr(VI) can affect macroorganism due to its oxidizing properties and ability to cross biological membranes causing an acute exposure. In microorganisms, the toxicity is mainly to the direct damage in biological membranes, cell structure, and protein function (Babich et al. 1980, Breton et al. 2013, Lemire et al. 2013, Hose et al. 2016, Assefa and Köhler 2020, Bojarski et al. 2021). The presence of MPs together with metal ions is well known (Pietroiusti et al. 2015, Häder et al. 2020). However, studies of the synergic effects of MPs and metal ions on host physiology and host-microbiome dysbiosis are needed. 


\subsection{Aims of the thesis}

In this thesis I use laboratory experiments on a variety of aquatic arthropods to answer the following questions:

1. Is the diversity of the host-microbiome affected by single and mixed exposure to MPs and toxicants? (I - IV)

2. How does diet affect the host-microbiome in single and mixed exposure to MPs and toxicants? (I and II)

3. How do single and mixed exposure to MPs and toxicants affect host life-history traits? (I, III and IV)

4. How do single and mixed exposure to MPs and toxicants affect feeding behavior? (II)

5. How do single and mixed exposure to MPs and toxicants affect host-microbiome through the trophic chain? (II)

6. Do single and mixed exposure to MPs and toxicants affect the free-living microbiome in the same way as the host-microbiome? (II-IV) 


\section{Methods}

\subsection{Microcosms}

I tested the effects and interactions of MPs and toxicants (esfenvalerate, deltamethrin (pyrethroids) or sodium dodecyl sulfate or chromium VI) on Chironomus riparius (Meigen 1804), Daphnia magna (Straus, 1820), damselfly larva Ischnura elegans (Vander Linden, 1820), a wild dragonfly larva Aeshna cyanea (Müller, 1764), a water boatman from the family Corixidae (Leach, 1815), and their microbiome. All the aforementioned pollutants are of high environmental and biological importance because they converge in water sources thus affecting non-target water arthropods. Chapter I used clay as bottom substrate for microcosms. Chapter II-IV used fresh water to perform the microcosms (Figures 1-4). I performed the experiments with 1 $\mu \mathrm{m}$ polystyrene-based latex spheres MPs (CAS\# 0009003536, Polysciences, Inc.). But in chapter II, I used $3 \mu \mathrm{m}$ MPs.

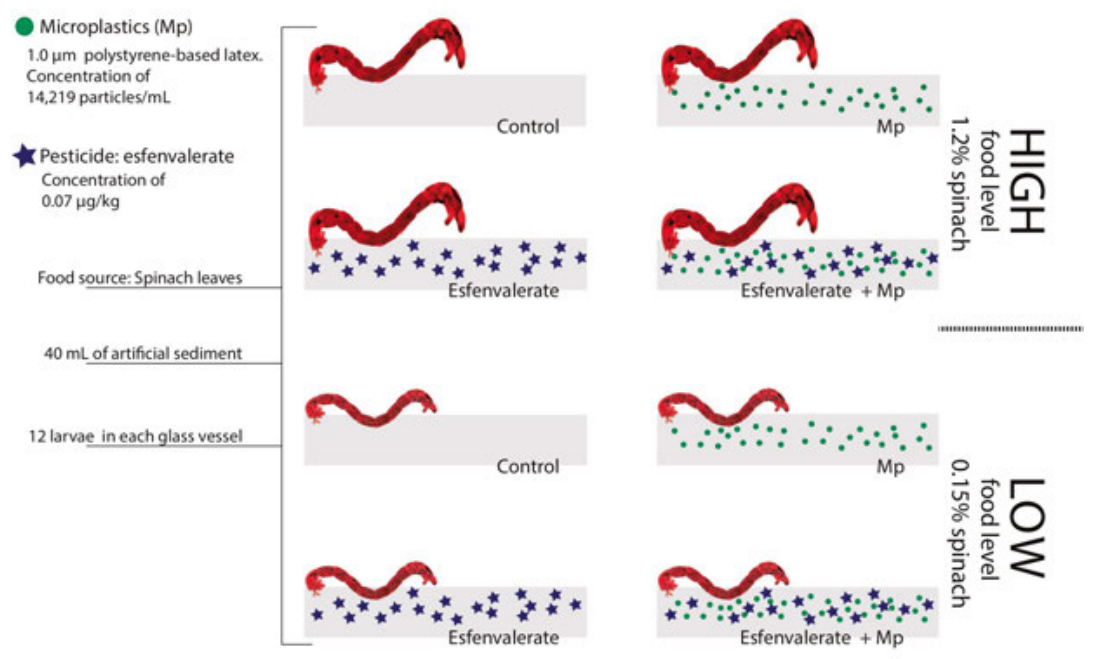

Figure 1. Experiment design of chapter I. The experiment was carried out in 165 $\mathrm{mL}$ glass jars containing artificial sediment and dechlorinated tap water to provide a ratio of sediment to overlying water of $1: 4$. The vessels were maintained at $19 \pm 1{ }^{\circ} \mathrm{C}$ and a 18:6 hour (light:dark) photoperiod. Due to fungal contamination the number of replicates ends as follow for the high food level: Control 11, MPs 11, esfenvalerate 16, and MPs+Esfenvalerate 13 replicates. Low food level: Control 28, MPs 27, esfenvalerate 25, and MPs+Esfenvalerate 25 replicates. 


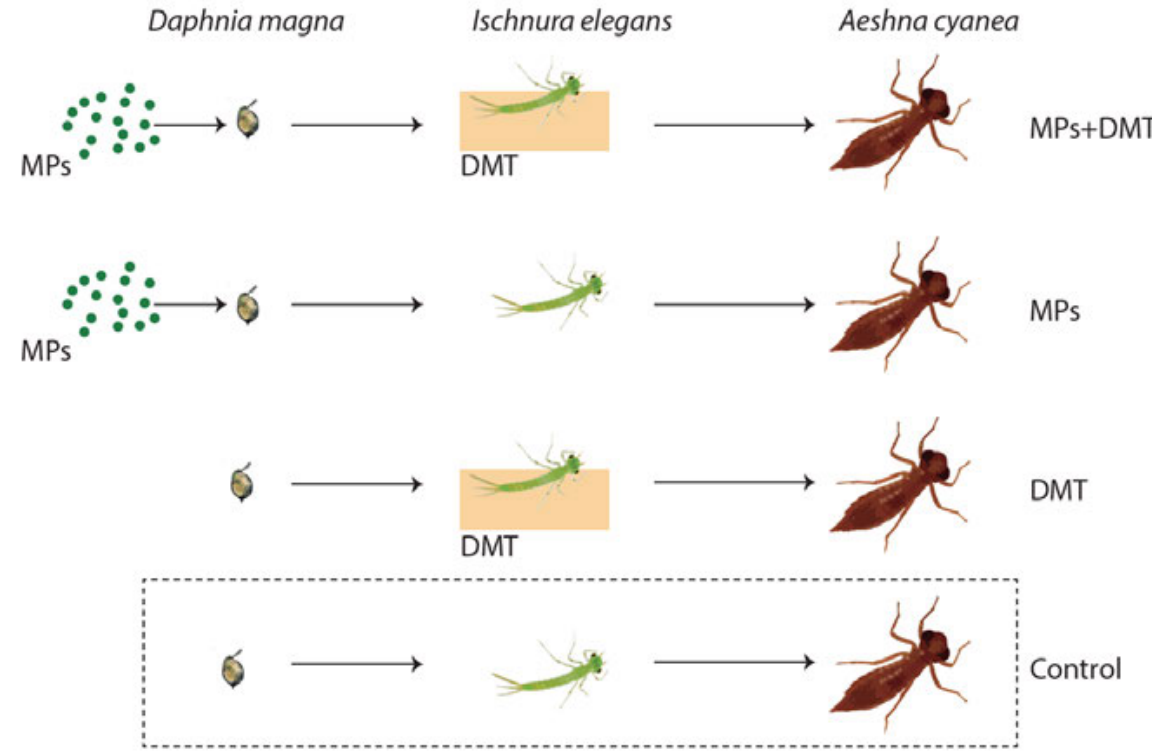

Figure 2. Overview of the experiment design of chapter II. D. magna was exposed to a control without MPs and a $3 \mu \mathrm{m}$ of polystyrene-base latex MPs in a concentration of $7.8 * 10^{5}$. I. elegans were exposed and not exposed to $0.2 \mu \mathrm{g} / \mathrm{L}$ of deltamethrin and fed with D. magna exposed to or not to MPs. A. cyanea were feed with $I$. elegans exposed to the three treatments. A total of $15 \mathrm{~A}$. cyanea were tested individually per treatment. Dechlorinated tap water was used to perform the experiment.

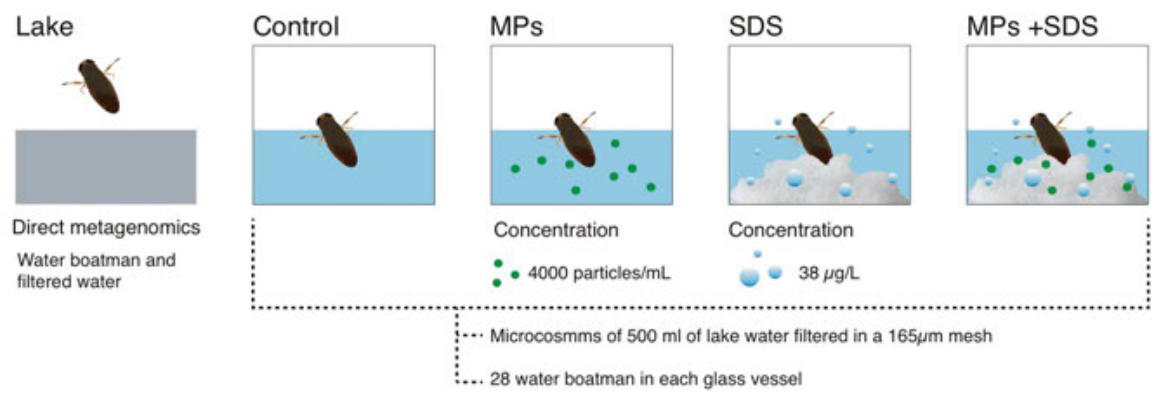

Figure 3. Graphical representation of the experimental design of chapter III. Heteroptera water boatmen from the family Corixidae were exposed to $1 \mu \mathrm{m}$ polystyrene-base latex MPs, sodium dodecyl sulfate (SDS), and the combination of both MPs and SDS. Water boatmen in the control were not exposed to MPs or SDS. The lake treatment is the direct metagenomics of the water boatman and the $165 \mu \mathrm{m}$ filtered lake water (i.e. No microcosm was made for the lake treatment), 6 replicates per treatment were used. 


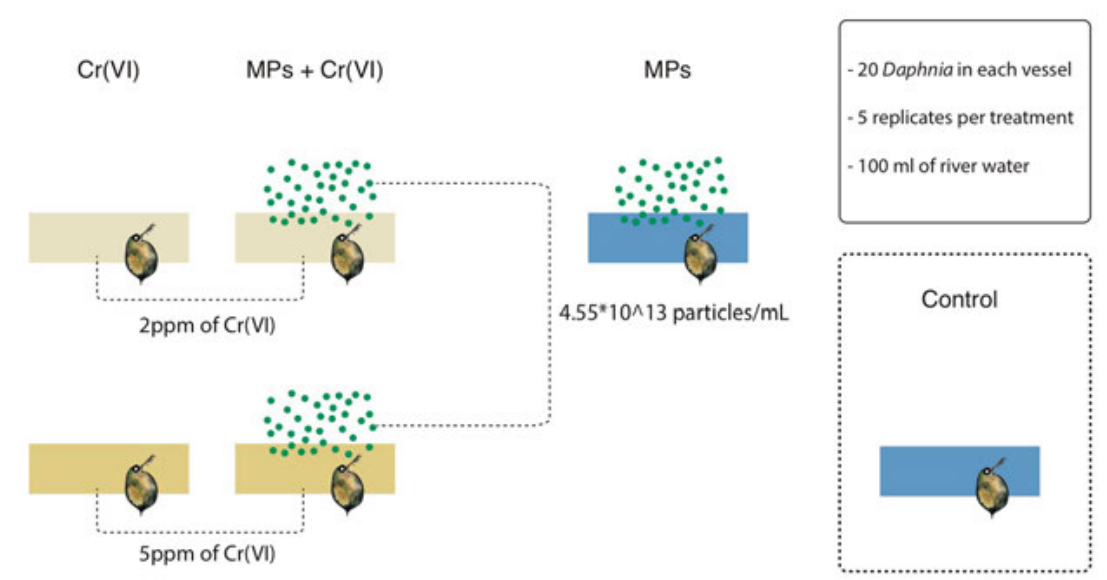

Figure 4. Experimental design of chapter IV. D. magna was exposed to $1 \mu \mathrm{m}$ polystyrene-base latex MPs, two concentrations of $\mathrm{Cr}(\mathrm{VI})$, and the combination of both MPs and Cr(VI). Daphnids were not exposed to MPs or Cr(VI) in the control. Water from the river Fyrisån, Uppsala Sweden was used in the experiment and 5 replicates per treatment were used.

\subsection{DNA extraction and library preparation}

All organisms were rinsed with Mili Q water prior to microbial extraction and analysis to avoid microbes from the water. The microbiome from the water was extracted from each replicate filtered with $0.2 \mu \mathrm{m}$ filter. DNA was extracted from the tested organism and the filter using DNeasy Powersoil (Qiagen, No./ID: 12888-10) as recommended in the manufacturer's protocol with an additional incubation at $65^{\circ} \mathrm{C}$ for $10 \mathrm{~min}$ after adding the $\mathrm{C} 1$ solution and additional 30 minutes of the bead homogenizer step. The $16 \mathrm{~S}$ ribosomal RNA gene was amplified in a two-step PCR using primer pair $515 \mathrm{~F}$ and 805R that flanks the hypervariable region V4. For the first step, PCRs were performed in triplicate using Phusion High-Fidelity DNA polymerase (Thermo Fisher Scientific, No./ID: F-530XL). Thirty cycles were performed following the Phusion polymerase protocol. Negative controls were run during DNA extraction and 16S PCR amplification to check for contamination. Triplicate PCR products of each sample were pooled and subsequently purified using AMPure XP magnetic beads (Beckman Coulter, No./ID: A63882). For the second step, Illumina adaptor sequences and barcodes were attached to the PCR primers to provide each sample with a unique identifier. Samples were then purified again using magnetic beads. An equal concentration of DNA from each sample was pooled and run through agarose gel. Then, the 400-500 bp band was excised and purified using the QIAquick gel extraction kit (Qiagen, No./ID: 28104). PCR products were sequenced on Illumina- 
MiSeq to obtain 250 bp paired-end reads at Science for Life Laboratory (SciLifeLab, Uppsala, Sweden).

\subsection{Sequencing data statistical analysis}

In all the chapters I- IV, the tested organisms microbiome amplicon sequence variant (ASV) tables were created using demultiplexed data sequenced by the SciLifeLab and following the DADA2 pipeline 1.8 (Callahan et al. 2016). The alpha diversity and the most abundant phyla were calculated using the R packages lattice (Sarkar, 2008) and MASS (Venables and Ripley, 2002). A diversity analysis (phylogenetic, Shanon and Chao) was performed to obtain ASV phylogenetic biodiversity, ASV evenness, and ASV richness, using the R package fossil (Vavrek 2011), vegan (Oksanen et al. 2018), ape (Paradis and Schliep 2019), and picante (Kembel et al. 2010). To test the effects of the exposure to MPs and the associated toxicant on the microbial alpha diversity, linear models were carried out using the diversity indexes as the response variable and the exposure to MPs and the associated toxicant (presence/absence) as fixed effects. Due to lack of normality, data were transformed ( $\log 10$ or square root transformed) or tested through permutation analysis with 9999 permutations to confirm the robustness of the parametric model (Hothorn et al. 2006). Post-hoc tests were carried out for pairwise comparisons using the R packages FSA (Ogle et al. 2020) and rcompanion (Mangiafico, 2020).

The beta diversity was assessed also for all chapters I-IV using Permutational Multivariate Analysis of Variance (PERMANOVA) using the R package vegan (Oksanen et al. 2018). The ASV distance matrix was used as a response variable, including the exposure to MP and DMT (presence/absence) as factors. To observe how the microbial communities cluster between treatments, a Principal Coordinates Analysis (PCoA) was performed. A Multivariate Analysis of Variance (MANOVA) was assessed using the top 4 or top 6 most abundant phyla as a response variable and MPs and the associated toxicant as fixed factors. To observe the effects of MPs and the associated toxicant in the relative abundance of the individual most abundant phyla, a Generalized Linear Model (GLM) with a quasi-Poisson family were performed. All the statistical analyses were executed in R statistical Computing Language 3.6.2 (R Core Team 2020). The phylogenetic tree and the taxonomy plots were created using Qiime 1.9.9 (Caporaso et al. 2012). 


\subsection{Life history statistical analyses}

In chapter I, Binomial generalized linear models with a logit link function were performed to assess the effects of MPs and esfenvalerate on the survival, emergence, and sex ratio on Chironomid larvae. A Generalized Linear Mixed Model (GLMM) with family Poisson and random effects was run to test the effects of the MPs and esfenvalerate on the Chironomid development time using vessel as a random effect. In chapter II, to test the effects of the MPs and the DMT on the damselfly survival against dragonfly predation at 10, 20, 30, 60, 120 180, 840, and 1440 minutes a Generalized Linear Mixed Models (GLMM) with multivariate normal random effects, using Penalized quasi-likelihood was performed using MASS (Venables and Ripley 2002) and nlme R packages (Pinheiro et al. 2020). Predated damselfly was used as the response variable, time was entered as a covariate, and MP and DMT as fixed factors. Dragonfly ID was entered as a random effect and to account for repeated measures an autocorrelation was included with time as continuous covariate and dragonfly ID as a grouping effect. In chapter III, to analyze the effect of MPs and SDS individually and their combined effects on the mortality (\%) of the water boatman at $24,48,72$, and $168 \mathrm{~h}$ a Poisson GLM was performed at each individual time. In chapter IV, the effects of MPs (two-level factor: presence/absence) and $\mathrm{Cr}(\mathrm{VI})$ (three-level factor $0,2,5 \mathrm{ppm}$ ) on the D. magna mortality at $12,18,24,28,30,40,52,66$, and 72 hours was tested using Generalized Least Squares fit model (GLS) using nlme R packages (Pinheiro et al. 2020). To account for repeated measures an autocorrelation was included with time as a continuous covariate and $D$. magna vessel as a grouping effect. An additional quasipoisson Generalized Linear Model (GLM) was used to assess the effects of MPs (two-level factor: presence/absence) and $\mathrm{Cr}(\mathrm{VI})$ (three-level factor 0,2,5 ppm) at $40 \mathrm{~h}$ and $72 \mathrm{~h}$ individually.

In all cases post-hoc test were performed to observe differences between treatments using the functions emtrends and emmeans of the R package emmeans (Lenth et al. 2020). All the models were also executed in R statistical Computing Language 3.6.2(R Core Team 2020). 


\section{Results and Discussion}

\subsection{Effects of MPs alone on the host-microbiome}

There were host-specific effects of MPs on host-microbial communities. For

C. riparius, there was no major effect due to MPs, and I found that only Shannon microbial diversity index was affected significantly due to the MPs (Chapter I). Significant changes in diversity and abundance of gut microbiome due to MPs have been shown before in vertebrates, in contrast to the low effects that I found in C. riparius (Lu et al. 2018, Jin et al. 2019). Interestingly, in chapter I, I also found that the microbial diversity was highly dependent on the level of food (high or low, Figure 5a). Similar effects of diet in the microbiome have been found in other aquatic organisms such as perch and arctic char (Nyman et al. 2017, Zha et al. 2018). In contrast, the experiments in chapter II showed that the MPs strongly affected the microbiomes of D. magna, the damselfly I. elegans, and dragonfly A. cyanea, Figure $5 \mathrm{~b}$. For the water boatmen microbiome in chapter III, I found effects of MPs on cyanobacteria, but did not find effects on microbial diversity (Figure 6a). I did not find significant effects of MPs on individual phyla on the $D$. magna microbiome in chapter IV (Figure 6b). I hypothesize that these differences among organisms could be explained in part by the size of the MPs as well as the MPs potential to be used as a carbon source and as a new colonization substrate (Zettler et al. 2013, Horton et al. 2018). It has been found previously that the effects of MPs vary depending on the size, the shape and material of the MPs (Besseling et al. 2014, Ma et al. 2016, Rist et al. 2017, Aljaibachi and Callaghan 2018, Felten et al. 2020). In chapter II, the differences observed could also be due to food chain effect where the severe changes in the microbiome found in the higher trophic levels could be due to the initial stress that the prey D. magna experience. Even if the MPs might or might not be in the individual after consumption is still the effect of the MPs on the consumer that is affecting individual's host microbiome. However, if the cause is due to direct effects of microplastic transfer or any indirect effect carried over via the predation remains to be investigated. 


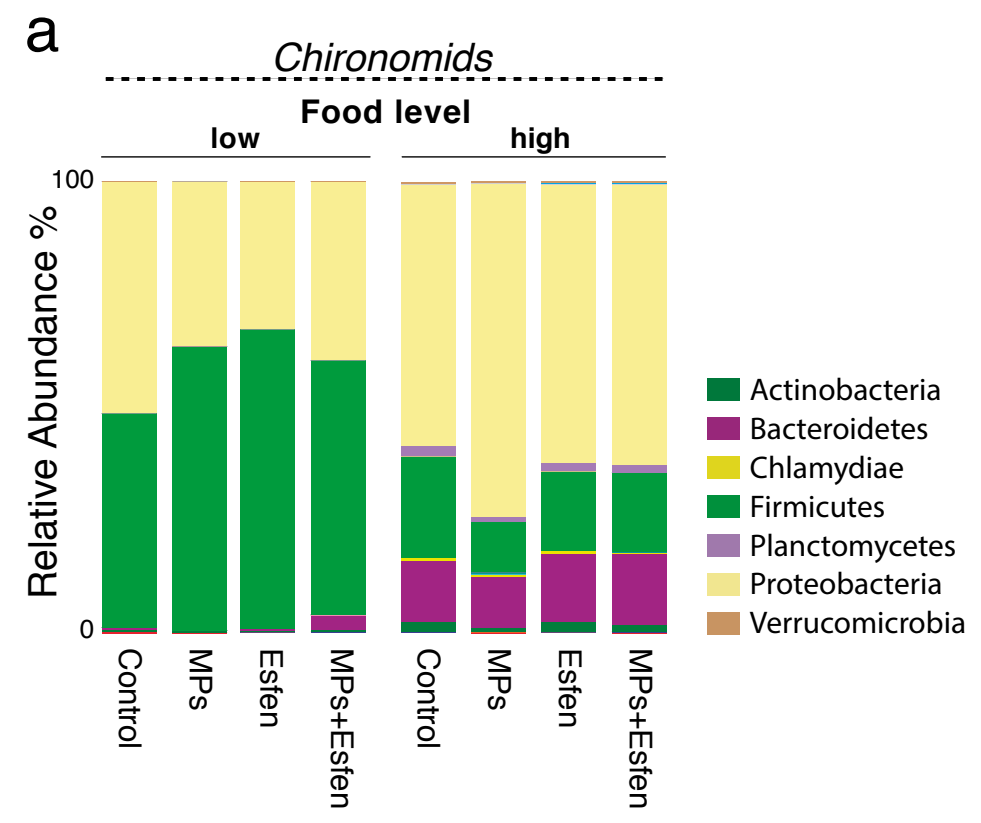

b

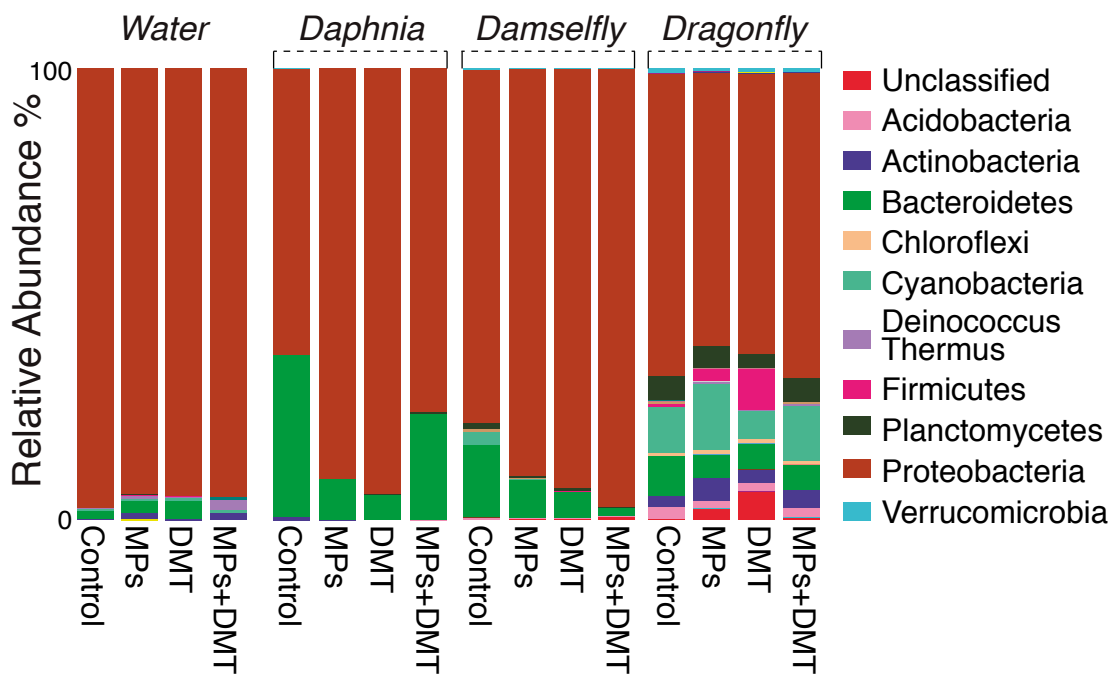

Figure 5. Phylum-level taxa diversity of a) the microbiome of $C$. riparius; the experiment was run at low and high food levels, b) Daphnia, Damselfly and Dragonfly's microbiome including the relative abundance of the water microbiome. Treatments were exposure to MPs and/or the toxicants esfenvalerate (Esfen), or DMT. The control replicates were not exposed to either MPs or any toxicants. 


\subsection{Effect of single toxicants in the host-microbiome}

The pesticide esfenvalerate did not show significant effects in the microbiome of the chironomids (Figure 5a). Though there were observable changes in the microbiome, pesticide concentration may not have been high enough to affect the host microbiome and the host as microbial environment (Chapter I). On the other hand, in the experiments of chapter II-IV the toxicants highly affected the host-microbiome of the aquatic organism tested (Figure $5 \mathrm{~b}, 6 \mathrm{a}$ and $\mathrm{b}$ ). This is not surprising, since DMT is known for its neurotoxic effects that can cause stress in the host which affects its microbiome (Mestres and Mestres 1992, Toshio 1992, Hong et al. 2020), SDS is known for bactericidal and bacteriostatic effects which will directly affect the microbiome (Baker et al. 1941, Brandt et al. 2001, Mousavi and Khodadoost 2019), and $\mathrm{Cr}(\mathrm{VI})$ is known for being able to cross and disturb biological membranes affecting microorganism in the microbiome with no resistance mechanisms (Babich et al. 1980, Breton et al. 2013, Hose et al. 2016, Assefa and Köhler 2020, Bojarski et al. 2021). We argue that this effect depends directly on the toxicity of the toxicant itself. However, after inspecting the microcosm water used in chapter II-IV, I found that these toxicants influence the water microbiome in a similar way or even with more significant effects in diversity and abundance than in the host-microbiome. The severe observed dysbiosis in the water compared to the one observed in the hostmicrobiome might be explained due to the hosts ability to adjust the host environment, and resist the pollutants in the environment through mechanisms of multidrug resistances (Kurelec 1992). Due to its intrinsic characteristics, the host regulates the microbiome, being under strong natural selection to control its microbiota as it is the environment colonized by the microbiota (Foster et al. 2017, Berg et al. 2020). In general, changes in the host environment jeopardize the host itself so under pollutant stress the host has defense mechanisms to expel the stressor and maintain this environment(Kurelec 1992). 
a
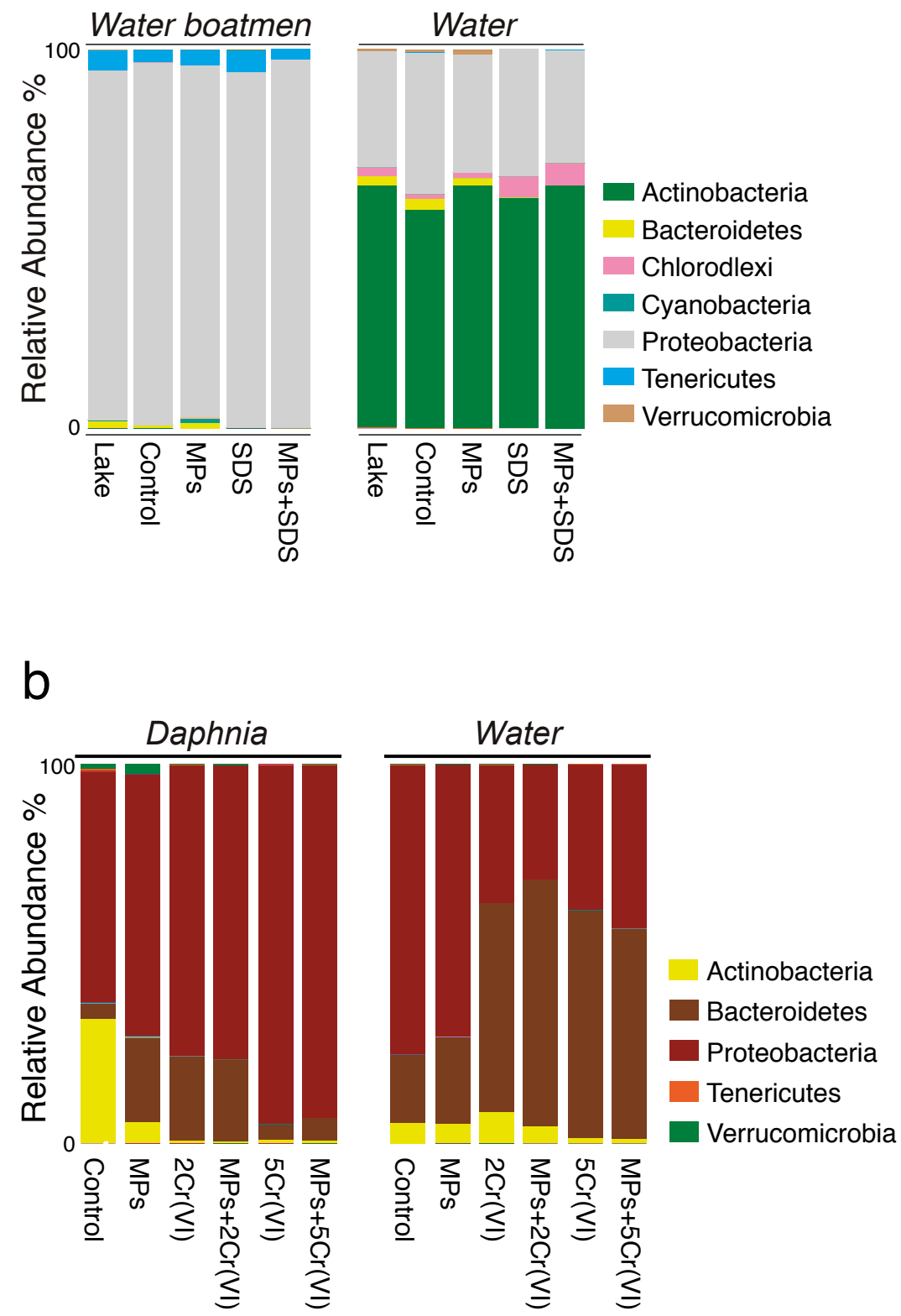

Figure 6. Phylum-level taxa diversity of a) Water boatman microbiome including the relative abundance of the water microbiome, and b) D. magna microbiome including the relative abundance of the water microbiome. Treatments were exposure to MPs and/or the toxicants SDS, or $\mathrm{Cr}(\mathrm{VI})$. The control replicates were not exposed to either MPs or any toxicants. 


\subsection{Combined effects of MPs and toxicants on the host- microbiome}

In chapter I, I found no effects in the host-microbiome abundance, richness, and diversity in response to the combined MPs and esfenvalerate (Figure 5a). One explanation could be that that microplastics might adsorb esfenvalerate from the water, reducing the concentration and exposure to larvae and microbes (Liu et al. 2020, Menéndez-Pedriza and Jaumot 2020). Nevertheless, the combined MPs and toxicant did show significant effects on some of the six top individual phyla of the host-microbiome (Chapter I-IV). I observed that the combined exposure of MPs and toxicants on the hostmicrobiome negatively affected the abundance in damselflies, dragonflies, and water boatmen of Bacteroidetes but positively affected the abundance of Proteobacteria in daphnids, damselflies, dragonflies, and water boatmen (Figure 5 and 6). Previous studies have shown that a decrease in Bacteroidetes abundance might result in abnormal intestinal permeability and pro- obesity phenotype (Joly Condette et al. 2015, Fang et al. 2018, Yuan et al. 2019). In addition, the increase of Proteobacteria might influence inflammation, lipid metabolism disorder, increase the susceptibility to infections, generate motor disabilities and gut diseases (Nasuti et al. 2016, Yuan et al. 2019). Therefore, such microbial changes might have a large effect on host health.

\subsection{Effect of MPs in host life-history traits}

I found that polystyrene-based latex spherical MPs that I used in my experiments did not have a strong effect on survival of the organisms tested here (Chapter I-IV) (Figure 7b, 8a and b). Depending on the material, MPs can be inert particles without any direct toxic effect (Cole et al. 2015b, Carbery et al. 2018, Wagner and Lambert 2018). Interestingly, the exposure to MPs reduced C. riparius emergence at low food levels (Figure 7a). This is a very important finding because even though mortality is low, MPs can still negatively impact adult emergence. Since mortality is usually the main endpoint used to assess if a pollutant is acceptable, I argue that other crucial lifehistory traits such as successful metamorphosis should be taken into consideration. 

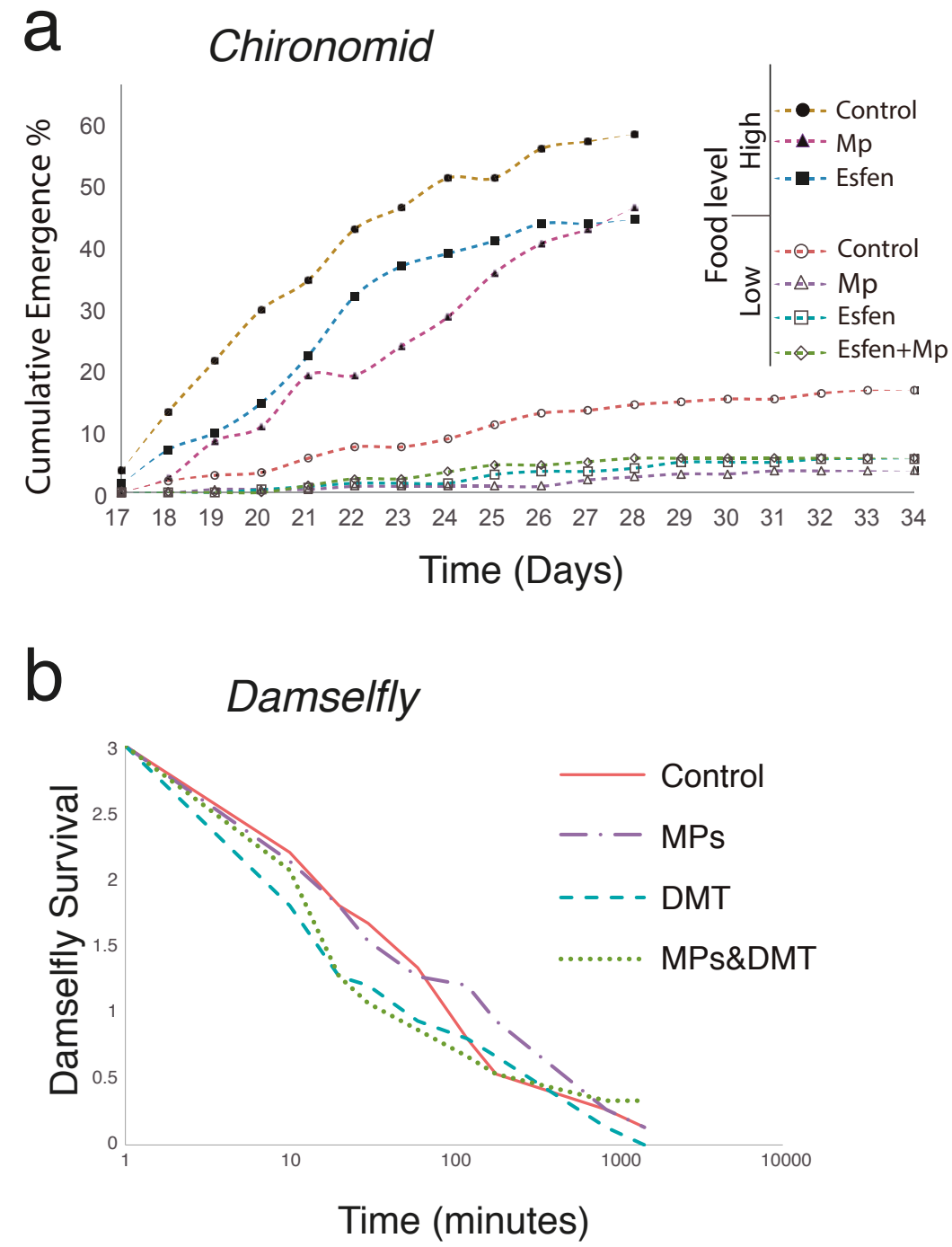

Figure 7. a) Cumulative emergence of $C$. riparius adults (males and females) over the course of 34 days in the low nutrient sediment and 28 days in the high nutrient sediment, b) Damselfly survival from dragonfly predation over time. The treatments were exposure to MPs, a toxicant; esfenvalerate (Esfen) or DMT, and combined exposure to MPs and toxicant or to none of these stressors (Control). 


\subsection{Effect of single toxicants in the host life-history traits}

All the three tested toxicants had significant effects on the host mortalitysurvival (Chapter I-IV). Figure 7a shows that at low food levels, C. riparius larvae exposed to esfenvalerate had a significantly lower emergence than the controls (Chapter I). Negative effects on survival of $C$. riparius due to esfenvalerate exposure have been shown before (Kunce et al. 2015). Figure $7 \mathrm{~b}$ shows that the damselfly exposed to DMT had higher mortality compared to the control (Chapter II). This result fits with the effects that DMT has over the voltage-gated $\mathrm{Na}^{+}$channel of the nervous system (Mestres and Mestres 1992, Hong et al. 2020), affecting the damselfly ability to escape from the dragonfly predator. For the water boatman, prolonged/chronic exposure is required for a significant effect of SDS alone (Chapter III). This chronic effect of detergents had been reported previously in nematode Caenorhabditis elegans (Harada et al. 2007), making detergent toxic even under low concentrations if the exposure period in the environment is long. For $D$. magna, I found that both concentrations $2 \mathrm{ppm}$ and $5 \mathrm{ppm}$ of $\mathrm{Cr}(\mathrm{VI})$ are highly toxic (Figure 8b, chapter IV). I expected high mortality because these concentrations of $\mathrm{Cr}(\mathrm{VI})$ are based on previous mortality reports in aquatic organisms exposed to Cr(VI) (Kim et al. 2002, Vargas and Dussán 2016, Zhou et al. 2021). I find that this mortality correspond to the lethal concentration 50 at $24 \mathrm{~h}$ for a concentration of $5 \mathrm{ppm}$ of $\mathrm{Cr}(\mathrm{VI})$.

\subsection{Combined effects of MPs and toxicants in host life- history traits}

In chapter I, I showed that the combination of MPs and esfenvalerate lowered emergence when the level of food is low (Figure 7a) but I did not detect any additive negative effects. Conversely, Felten et al. (2020) did report additive negative effects on survival of D. magna in response to the combined exposure of MPs with DMT. Interestingly, I found in chapter II that in D. Magna microbial communities were significantly affected, specifically beta diversity and three of the six top phyla. However, I did not assess the survival of D. magna in my experiment. When I evaluated predation risk of A. cyanea by I. elegans, I did not find an interactive effect between MPs and DMT on damselfly survival (Figure 7b). In chapter III observed higher mortality in treatments with MPs combined with SDS at 24 and 48 hours (Figure 8a). I suggest that this interaction reduces the time needed for SDS to cause mortality. Though MPs could interact with organic toxicants (Skjolding et al. 2016, Wagner and Lambert 2018), the interaction between MPs and detergents remains unexplored. In chapter IV, I found a synergis- 
tic effect between MPs combined with a sublethal concentration of $2 \mathrm{ppm}$ of $\mathrm{Cr}(\mathrm{VI})$ that increased the mortality of D. Magna at 72 hours (Figure 8b). However, these studies are scarce, and similar studies only focused in the interaction effects between MPs combined with hydrophobic organic chemicals (Rochman et al. 2014, Felten et al. 2020). Since the interaction between MPs and toxic metal was the most toxic interaction, research on the effects of MPs combined with metal ions must be prioritized in future studies.
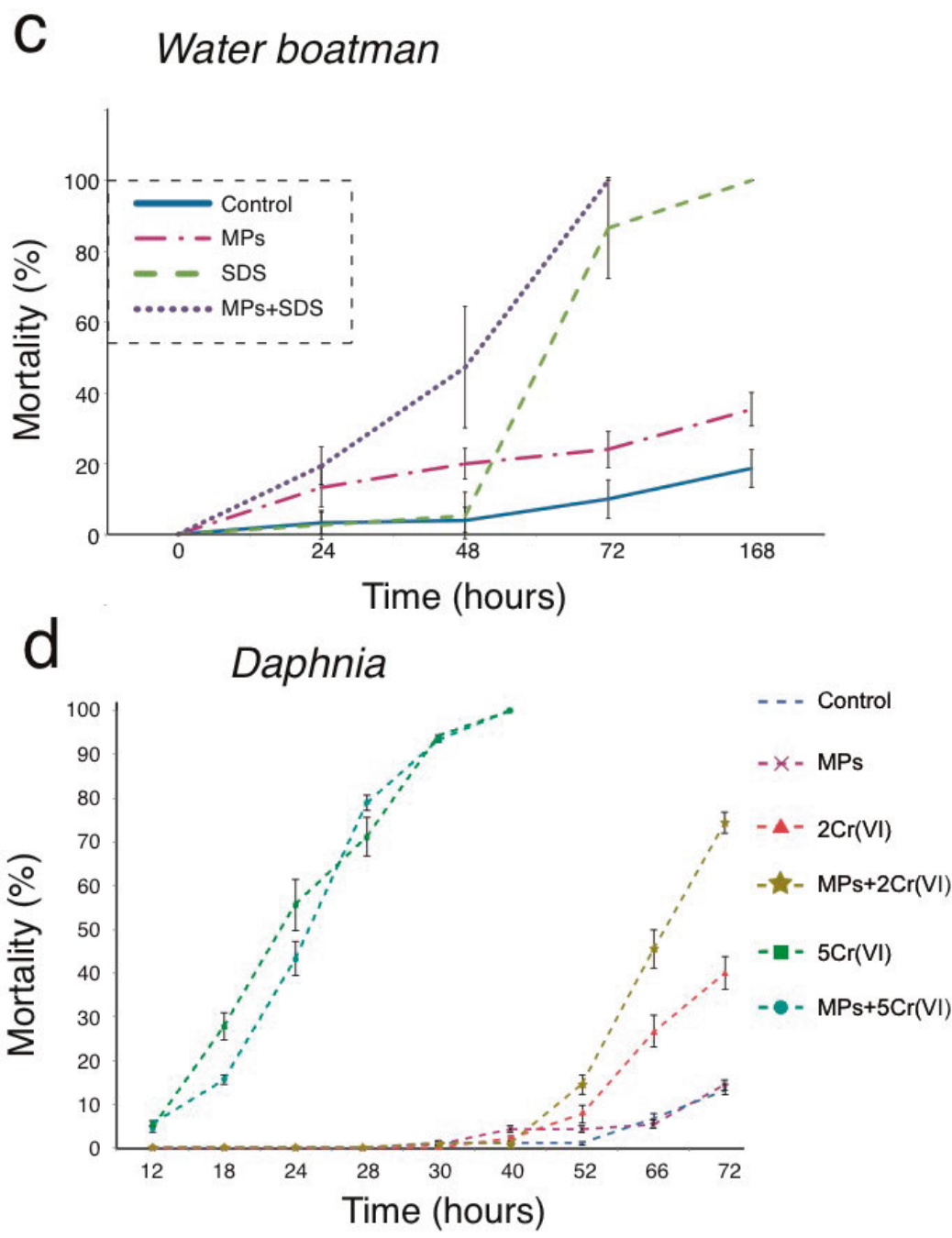

Figure 8. a) Mortality of water boatman, and b) mortality of D. Magna. The treatments were exposure to MPs, and toxicant; SDS or $\mathrm{Cr}(\mathrm{VI})$, and a combined exposure to MPs and toxicant or to none of these stressors (Control). 


\section{Conclusions}

This thesis highlights the importance of understanding the cocktail effects of pollutants on host fitness and its microbiome. I showed that microplastics could cause indirect effects on the predator microbiome when a top predator fed on prey that has been exposed to this pollutant. I also observe microbial perturbations or dysbiosis at the top and intermediate predator when the prey had been exposed to a cocktail of a toxicant and the microplastics. I have evidence that hosts such as Daphnia magna and the chironomids consume the microplastics though I do not have evidence that the microplastics are transferred to the other trophic levels. I hypothesize that MPs in the $D$. magna could increase stress in the individual itself. This means that the changes in the microbiome of the top predator could be due to the stress response in the prey together with the effects of the microplastics. Thus, even if the MPs are not in the individual after consumption, MPs can indirectly affect the predator individual's gut microbiome. This thesis is of importance for recognizing the hazards of MPs combined with a toxicant as well as for assessing other ways that multiple pollutants can affect an organism such as host microbiome, metamorphosis, and trophic chain effects in aquatic environments. 


\section{Svensk sammanfattning}

I många ekosystem växelverkar/interagerar ett djurs biologi ofta med olika antropogena föroreningar. Mer specifikt är interaktionen mellan ett värddjur och dess associerade mikrobiom en av huvudnycklarna för att förstå effekterna av miljö-reglerade störningar på egenskaper så som hälsa, beteende, och evolution av värddjuret. Antropogena aktiviteter resulterar ofta i stressresponser hos djur vilket kan ha en stark påverkan på djurets mikrobiom, inklusive mikroorganismerna i mag-tarmkanalen. Tidigare studier har visat att kemikalier $\mathrm{i}$ omgivningen och andra stress-inducerande faktorer kan skapa stora förändringar i magens mikrobiom hos djur. Därför är det viktigt att studera just hur förändringar i värdens mikrobiom, framförallt mångfald och sammansättning, påverkas av miljöföroreningar.

Mikrobiomstudier är viktiga eftersom mikrobiomet fungerar som en biologisk barriär och kan påverka till exempel immunförsvarsreglering, matsmältning, näringsupptagning, tarmrörelser, och även beteende hos värdorganismen. Den här avhandlingen bidrar med att reda ut de multidimensionella effekterna av mikrobiomet på stress och hälsa hos några utvalda vattenlevande leddjur. Målet med forskningen i den här avhandling är att förstå effekterna av mikroplast-föroreningar och giftiga föroreningar så som insektsgift, tvättmedel, metaller, och interaktionerna mellan dessa två grupper på värd-mikrobiomet hos olika modell-organismer. Jag studerade även de sekundära effekterna av stressfaktorerna samt hur effekterna kan spridas i födo-kedjor. För att testa detta gjorde jag mikrokosmexperiment där jag utsatte olika vattenlevande insekter och kräftdjur för mikroplaster tillsammans med olika typer av miljö-gifter.

Jag började med att testa effekterna av mikroplaster och insektsgiftet esfenvalerate (en syntetisk pyretroid) på fjädermygglarven Chironomus riparius överlevnad, tillväxt, och mikrobiom. Efter det testade jag effekterna av mikroplaster och insektsgiftet deltamethrin (en pyretroid ester) på en trofisk kedja (födo-kedja) med tre organismer: Daphnia manga (vattenloppa), Ischnura elegans (flickslända), och Aeshna cyanea (trollslända). I den tredje studien testade jag effekterna av mikroplaster och natriumlaurylsulfat (som finns i tvättmedel) på dödlighet hos värddjuret och effekterna på värddjurets mikrobiom hos buksimmare från Corixidae-familjen. Slutligen testade jag effekterna av mikroplaster och Krom(VI) på Daphnia magnas dödlighet och 
på dess mikrobiom. Jag använde mig av metagenomiska verktyg för att analysera både värd-mikrobiomet, och vatten-mikrobiomet i de mikrokosm jag undersökte. Mina resultat visade att mikroplaster kan interagera med additiva gifter och förändra värd-mikrobiomet. De specifika effekterna på mikrobiomets diversitet och sammansättning beror på typen av gift, storleken på mikroplasterna, och vilken värdorganism som studerades. Mina studier belyser vikten av att samstudera interaktiva faktorer (cocktail-effekter) som gifter för att bättre förstå hur dessa påverkar djurens hälsa och mikrobiom. Jag visade dessutom att mikroplaster kan orsaka indirekta effekter på mikrobiomet när rovdjur ansamlar dessa genom sina byten. Jag observerade mikrobiella störningar så kallad dysbios från den andra trofiska nivån när rovdjur konsumerade byten utsatta för diverse gifter och mikroplaster.

Den här avhandlingen visar komplexiteten i interaktionerna mellan mikroplaster och additiva gifter som ett blandat system och dess effekter på värdmikrobiomet. Mina studier utforskar samband mellan mikrobiomet, mikroplaster, och värd-hälsa, och hur dessa påverkas av additiva gifter. 


\section{Acknowledgements}

Financial support for chapter I came from the Oscar Lili Lamm Memorial fund (DO 2011-0014) and the Uppsala University Zoological Foundation. Chapter I and II got support from the Swedish Research Council (VR, 2016-04015). Chapter II got additional support the Department of Ecology and Genetics. Chapter III and IV got finacial support from Linnéska stipendiestilftelsen and the Department of Ecology and Genetics. I thank to Nemira Žilinskaitè, Malin Bohman Gineta Šukytè, Gabrielè Ivaščenkaitè and Tania Safa for their invaluable contribution collecting the water samples and performing microcosms at Erken research school in the summer of 2016. I also thank to Erken research school for providing their installations and help for this experiment in the chapter III. Christoffer Mattson for his valuable help in the fieldwork and in the experimental set up, as well as Christoffer Bergvall for his help with the $\mathrm{Cr}(\mathrm{VI})$ measurements using the HPLC in chapter IV. I thank to Chaz Hyseni for his comments on chapter III, and Leah Mupas Segui proof reading this thesis, chapter III, and chapter IV.

Sequencing was performed by the SNP\&SEQ Technology Platform in Uppsala. The facility is part of the National Genomics Infrastructure (NGI) Sweden and Science for Life Laboratory. The SNP\&SEQ Platform is also supported by the Swedish Research Council and the Knut and Alice Wallenberg Foundation.

\subsection{Acknowledgements 2.0}

It will not be good to have some more years as a PhD student? -What? Are you crazy? Of course it will! I loved this time of my life. First, I would like to acknowledge that I am afraid of what is coming and I think that is the main reason that I am excited to start this new phase in my life. - It is just life, so do not worry. A new phase that hopefully will be mostly full of good energy and happiness because I will have all you with me. Maybe also you! -Are you talking to the reader? Are you OK? Yes, you that does not know me but took the time to read this thesis that is part of me, but I am afraid to say that is not the best part of me-So, what was your point with that? Are you trying to tell us that we are the best part of you? 
As usual I want to thank my family for all their support, my mother and father for their trust and encouragement (no sería nadie sin ustedes! Su apoyo y su amor es mi guia. Gracias Pá, Gracias Mami). - And the traumas, do not forget the traumas. I will say my mother again for being always there and give me strength in the most difficult moments and my sister for being the best role model to follow. Without them I am sure nothing of this would be possible, and surely without my sister I probably would never embraced a scientific life.

Since I started this journey I must say I have been extremely lucky. I left Colombia looking for a cold land where people will feel the heat of my heart. -Dude really? And I arrived to Sweden, a country in the very north of the world just as I always desired since I was a child. - You just wanted to be alone. All my friends in that time asked me "why do you want that?" I still do not know -of course you do, you just wanted a place where you can be yourself! But I do know something, David Outomuro was right, I have been blessed with a star! -Aw thanks! Anyway, I think he was right because I meet him! I guess no matter the problems and all the difficulties we encountered, we are still friends and colleagues and that is very treasured to me. Surely there would be no thesis without him. When I arrived to Sweden I was not sure about a career in science. -You are still not sure. I was not sure about my knowledge or myself but Thanks to Anna Szekely I was able to trust myself and exploit my potential -best supervisor ever. Thank you for giving me the opportunity to work with you and for believing in me.

The road to be here was not easy but I was never alone. Maybe I complain too much, maybe I care too much -yes, you do but I am with you on this one, you had some nasty times. But in those times Frank Johansson was there. - Just do not ask first if he is doing well. He listened and gave to me guidance and a lot of help. Thank you for having the door of your office open and for dedicating your time to my thesis and me. - Maybe you bother too much. Maybe you should open your door too! I would like to thank my supervisor Richard Svanbäck for giving me the freedom to create and collaborate in several projects. -Those are not even in your thesis hahaha but you did have good time doing those. That sadly you cannot see in this thesis but hopefully you will see it published very soon.

I also want to thank Leah Mupas Segui, the best lab/office mate ever! -She totally wrote that part! And what about Daan? He is the Flying Dutchman We worked hard and played harder. - That one too, but it is totally true. OK, she is the best. Together we thank the Pink Panther. -I am sure Javi do not remember what happened in Pink Panther. I have so many good memories from that time that it will be impossible for me to share it here-Remember 
that time in the sauna or that time you both prayed to the PCR gods or the booze cruise, wait San Juan! Memories that will remain in my heart forever.

There were so many difficult times but life is holistic. Nothing comes out without something coming in. - You should be talking about the gym not holistic trash. There is no happiness without sadness. -Now everything is connected or what? When I was lacking of support I got a brother. Dr Baltzer himself wanted to be in my life. Thanks Nicholas, your help and friendship is invaluable, Boop! -Help? Are you sure that was help? You played video games instead of working. You are the best brother some one would ever wish and also the best roomie -I am sure he will shove this in his real brother's face. My dear Ylva, I am joking. You are the best roomie. $-\mathrm{I}$ don't know dude remember that time she kick you in the nuts while you were asleep. You are a lifesaver you opened your heart and give me a home in the moment I most needed. I love you both.

Of course, this will not be complete without talking about my friends in Colombia. To them and my family I owe what I am today. Mi Tata gracias por apoyarme por visitarme y por todas esas llamadas. Viktor next time will be your turn to hang up! Rafa do you remember Iceland? I could not ask for a better trip mate. Cesar thank you for hosting me while I was depressed I almost made Leuven my home -Knowing you this is going to be long and you are getting nostalgic already David Ayala and Laura Avellaneda you inspired me! For that I will be always thankful. That, the parties, and my short time in the BCEM at Andes University. -Remember Mauro, He helped you to understand all the bioinformatics stuff. Anyway, I am thankful because I am never alone! I have all of you in my life and the best necklace. Sof, you really gave me the best good luck charm

-Do you even imagine what people will think when they read all this? Of course someone must read it firs! My PhD was a trip with many homes and, many universities and I am grateful to all of them and their people. -I thought you would be more specific? Uppsala University (especially Limnology and Animal ecology), Andes University, Hólar University, Michingan State University and The University Centre in Svalbard. All this places are full of amazing people. Maggie (dupe) see you around! Salomé I am missing our picnics. Oli come visit! Mèrce I am still waiting for your party. Zuzana thanks for the old times. Come back soon Maria! Thanks for the parties Midsommar! You are the sunshine I need all year round $-\mathrm{I}$ do not think they will get it. Mil gracias... Tusen tack! 


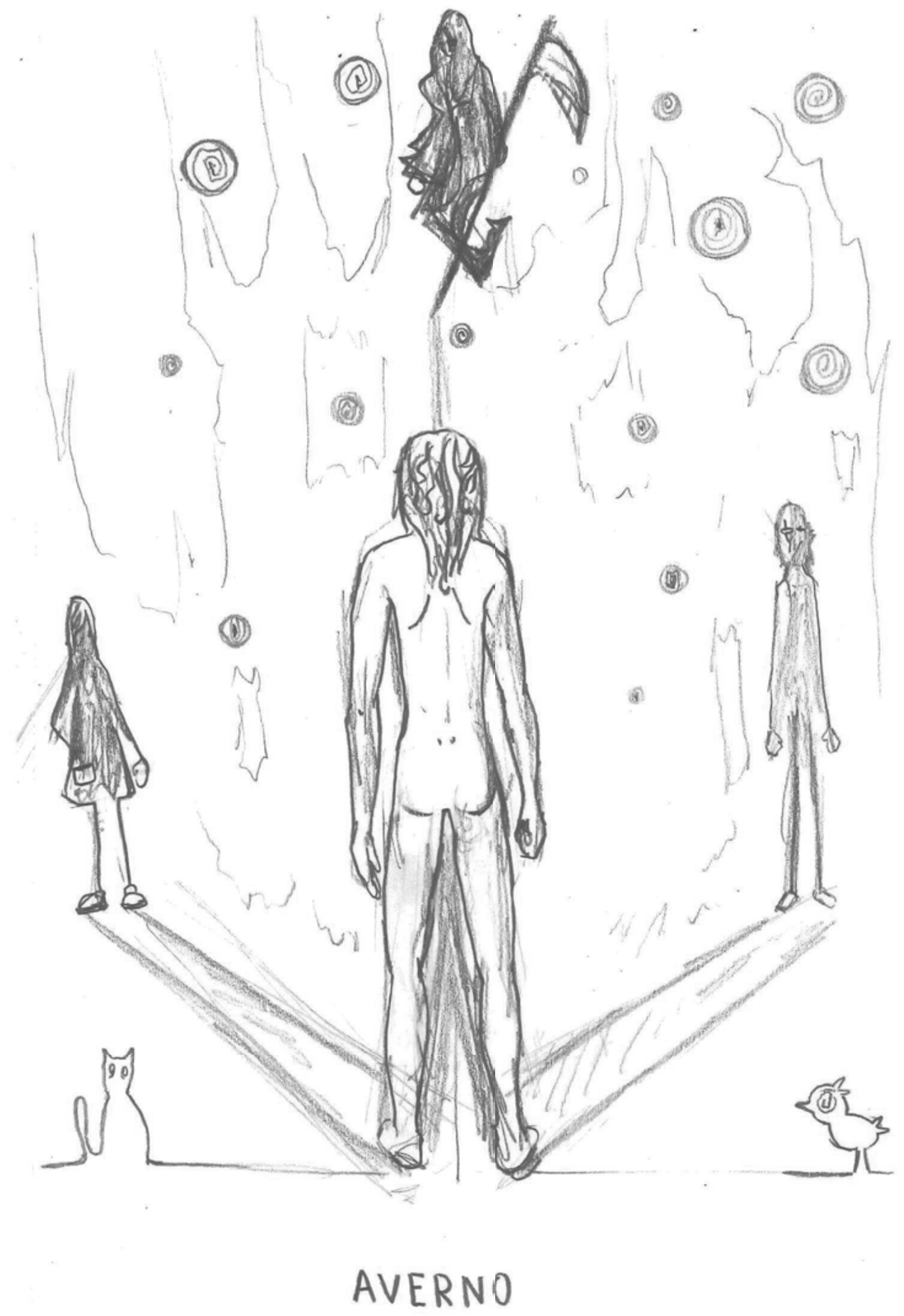




\section{Bibliography}

Aljaibachi, R., and A. Callaghan. 2018. Impact of polystyrene microplastics on Daphnia magna mortality and reproduction in relation to food availability. PeerJ 2018

Amaral-Zettler, L. A., E. R. Zettler, and T. J. Mincer. 2020. Ecology of the plastisphere. Nature Reviews Microbiology 18:139-151.

Amweg, E. L., D. P. Weston, J. You, and M. J. Lydy. 2006. Pyrethroid insecticides and sediment toxicity in urban creeks from California and Tennessee. Environmental Science and Technology 40:1700-1706.

Assefa, S., and G. Köhler. 2020. Intestinal microbiome and metal toxicity. Current Opinion in Toxicology 19:21-27.

Babich, H., G. Stotzky, and H. L. Ehrlich. 1980. Environmental factors that influence the toxicity of heavy metal and gaseous pollutants to microorganisms. Critical Reviews in Microbiology 8:99-145.

Baker, Z., R. Harrison, and B. Miller. 1941. Inhibition by phospholipids of the action of synthetic detergents on bacteria:621-637.

Beketov, M. A. 2004. Comparative sensitivity to the insecticides deltamethrin and esfenvalerate of some aquatic insect larvae (Ephemeroptera and Odonata) and Daphnia magna. Russian Journal of Ecology 35:200-204.

Berg, G., D. Rybakova, D. Fischer, T. Cernava, M. C. C. Vergès, T. Charles, X. Chen, L. Cocolin, K. Eversole, G. H. Corral, M. Kazou, L. Kinkel, L. Lange, N. Lima, A. Loy, J. A. Macklin, E. Maguin, T. Mauchline, R. McClure, B. Mitter, M. Ryan, I. Sarand, H. Smidt, B. Schelkle, H. Roume, G. S. Kiran, J. Selvin, R. S. C. de Souza, L. Van Overbeek, B. K. Singh, M. Wagner, A. Walsh, A. Sessitsch, and M. Schloter. 2020. Microbiome definition re-visited: old concepts and new challenges. Microbiome 8:1-22.

Bernhardt, E. S., E. J. Rosi, and M. O. Gessner. 2017. Synthetic chemicals as agents of global change. Frontiers in Ecology and the Environment 15:84-90.

Besseling, E., B. Wang, M. Lürling, and A. A. Koelmans. 2014. Nanoplastic affects growth of S. obliquus and reproduction of D. magna. Environmental Science and Technology 48:12336-12343.

Bojarski, B., O. Buchko, E. Kondera, K. Ługowska, A. Osikowski, M. Trela, M. Witeska, and M. W. Lis. 2021. Effects of embryonic exposure to chromium (VI) on blood parameters and liver microstructure of 1-day-old chickens. Poultry Science 100:366-371.

Bolnick, D. I., L. K. Snowberg, P. E. Hirsch, C. L. Lauber, E. Org, B. Parks, A. J. Lusis, R. Knight, J. G. Caporaso, and R. Svanbäck. 2014. Individual diet has sex-dependent effects on vertebrate gut microbiota. Nature communications 5:4500.

Brady, J. A., W. W. Wallender, I. Werner, B. M. Fard, F. G. Zalom, M. N. Oliver, B. W. Wilson, M. M. Mata, J. D. Henderson, L. A. Deanovic, and S. Upadhaya. 2006. Pesticide runoff from orchard floors in Davis, California, USA : A 
comparative analysis of diazinon and esfenvalerate. Agriculture Ecosystems \& Environment 115:56-68.

Brandt, K. K., M. Hesselsøe, P. Roslev, K. Henriksen, and J. Sørensen. 2001. Toxic Effects of Linear Alkylbenzene Sulfonate on Metabolic Activity, Growth Rate, and Microcolony Formation of Nitrosomonas and Nitrosospira Strains. Applied and Environmental Microbiology 67:2489-2498.

Breton, J., C. Daniel, J. Dewulf, S. Pothion, N. Froux, M. Sauty, P. Thomas, B. Pot, and B. Foligné. 2013. Gut microbiota limits heavy metals burden caused by chronic oral exposure. Toxicology Letters 222:132-138.

Browne, M. A., P. Crump, S. J. Niven, E. Teuten, A. Tonkin, T. Galloway, and R. Thompson. 2011. Accumulation of microplastic on shorelines woldwide: Sources and sinks. Environmental Science and Technology 45:9175-9179.

Butt, R. L., and H. Volkoff. 2019. Gut microbiota and energy homeostasis in fish. Frontiers in Endocrinology 10:6-8.

Callahan, B. J., P. J. Mcmurdie, M. J. Rosen, A. W. Han, and A. J. A. 2016. Dada2. Nat Methods 13:581-583.

Caporaso, J. G., C. L. Lauber, W. A. Walters, D. Berg-Lyons, J. Huntley, N. Fierer, S. M. Owens, J. Betley, L. Fraser, M. Bauer, N. Gormley, J. A. Gilbert, G. Smith, and R. Knight. 2012. Ultra-high-throughput microbial community analysis on the Illumina HiSeq and MiSeq platforms. ISME Journal 6:16211624.

Carbery, M., W. O'Connor, and T. Palanisami. 2018. Trophic transfer of microplastics and mixed contaminants in the marine food web and implications for human health. Environment International 115:400-409.

Cénit, M. C., V. Matzaraki, E. F. Tigchelaar, and A. Zhernakova. 2014. Rapidly expanding knowledge on the role of the gut microbiome in health and disease. Biochimica et Biophysica Acta - Molecular Basis of Disease 1842:1981-1992.

Cole, M., P. Lindeque, E. Fileman, C. Halsband, and T. S. Galloway. 2015a. The impact of polystyrene microplastics on feeding, function and fecundity in the marine copepod Calanus helgolandicus. Environmental Science and Technology 49:1130-1137.

Cole, M., P. Lindeque, E. Fileman, C. Halsband, and T. S. Galloway. 2015b. The Impact of Polystyrene Microplastics on Feeding, Function and Fecundity in the Marine Copepod Calanus helgolandicus.

Costa, M. F., J. A. Ivar, M. Christina, B. A. Ângela, and S. Paula. 2009. On the importance of size of plastic fragments and pellets on the strandline : a snapshot of a Brazilian beach.

Czyzewska, K. 1975. The Effect of Detergents on Larval D e v e 1 o p m e n t of a Crab.

Dawood, M. A. O., M. F. AbdEl-kader, E. M. Moustafa, M. S. Gewaily, and S. E. Abdo. 2020. Growth performance and hemato-immunological responses of Nile tilapia (Oreochromis niloticus) exposed to deltamethrin and fed immunobiotics. Environmental Science and Pollution Research 27:11608-11617.

Dehler, C. E., C. J. Secombes, and S. A. M. Martin. 2017. Environmental and physiological factors shape the gut microbiota of Atlantic salmon parr (Salmo salar L.). Aquaculture 467:149-157.

Douglas, A. E. 2016. How multi-partner endosymbioses function. Nature Reviews Microbiology 14:731-743.

Fang, B., J. W. Li, M. Zhang, F. Z. Ren, and G. F. Pang. 2018. Chronic chlorpyrifos exposure elicits diet-specific effects on metabolism and the gut microbiome in rats. Food and Chemical Toxicology 111:144-152. 
Felten, V., H. Toumi, J. F. Masfaraud, E. Billoir, B. I. Camara, and J. F. Férard. 2020. Microplastics enhance Daphnia magna sensitivity to the pyrethroid insecticide deltamethrin: Effects on life history traits. Science of the Total Environment 714:136567.

Forbes, V. E., and A. Cold. 2005. Effects of the pyrethroid esfenvalerate on lifecycle traits and population dynamics of Chironomus riparius--importance of exposure scenario. Environmental Toxicology and Chemistry 24:78-86.

Foster, K. R., J. Schluter, K. Z. Coyte, and S. Rakoff-Nahoum. 2017. The evolution of the host microbiome as an ecosystem on a leash. Nature 548:43-51.

Gerasimidis, K., K. Bryden, X. Chen, E. Papachristou, A. Verney, M. Roig, R. Hansen, B. Nichols, R. Papadopoulou, and A. Parrett. 2019. The impact of food additives, artificial sweeteners and domestic hygiene products on the human gut microbiome and its fibre fermentation capacity. European Journal of Nutrition.

Gould, A. L., V. Zhang, L. Lamberti, E. W. Jones, B. Obadia, N. Korasidis, A. Gavryushkin, J. M. Carlson, N. Beerenwinkel, and W. B. Ludington. 2018. Microbiome interactions shape host fitness. Proceedings of the National Academy of Sciences of the United States of America 115:E11951-E11960.

Guo, C., L. Ding, X. Jin, H. Zhang, and D. Zhang. 2021. Application of response surface methodology to optimize chromium (VI) removal from aqueous solution by cassava sludge-based activated carbon. Journal of Environmental Chemical Engineering 9:104785.

Häder, D. P., A. T. Banaszak, V. E. Villafañe, M. A. Narvarte, R. A. González, and E. W. Helbling. 2020. Anthropogenic pollution of aquatic ecosystems: Emerging problems with global implications. Science of the Total Environment 713:136586.

Hanning, I., and S. Diaz-Sanchez. 2015. The functionality of the gastrointestinal microbiome in non-human animals. Microbiome 3:51.

Harada, H., M. Kurauchi, R. Hayashi, and T. Eki. 2007. Shortened lifespan of nematode Caenorhabditis elegans after prolonged exposure to heavy metals and detergents. Ecotoxicology and Environmental Safety 66:378-383.

Hong, Y., Y. Huang, G. Yan, H. Yin, and Z. Huang. 2020. DNA damage, immunotoxicity, and neurotoxicity induced by deltamethrin on the freshwater crayfish, Procambarus clarkii. Environmental Toxicology:1-8.

Horton, A. A., M. G. Vijver, E. Lahive, D. J. Spurgeon, C. Svendsen, R. Heutink, P. M. van Bodegom, and J. Baas. 2018. Acute toxicity of organic pesticides to Daphnia magna is unchanged by co-exposure to polystyrene microplastics. Ecotoxicology and Environmental Safety 166:26-34.

Hose, G. C., K. Symington, M. J. Lott, and M. J. Lategan. 2016. The toxicity of arsenic(III), chromium(VI) and zinc to groundwater copepods. Environmental Science and Pollution Research 23:18704-18713.

Hothorn, T., K. Hornik, M. A. Van De Wiel, and A. Zeileis. 2006. A lego system for conditional inference. American Statistician 60:257-263.

Huttenhower, C., D. Gevers, R. Knight, S. Abubucker, J. H. Badger, A. T. Chinwalla, H. H. Creasy, A. M. Earl, M. G. Fitzgerald, R. S. Fulton, M. G. Giglio, K. Hallsworth-Pepin, E. A. Lobos, R. Madupu, V. Magrini, J. C. Martin, M. Mitreva, D. M. Muzny, E. J. Sodergren, J. Versalovic, A. M. Wollam, K. C. Worley, J. R. Wortman, S. K. Young, Q. Zeng, K. M. Aagaard, O. O. Abolude, E. Allen-Vercoe, E. J. Alm, L. Alvarado, G. L. Andersen, S. Anderson, E. Appelbaum, H. M. Arachchi, G. Armitage, C. A. Arze, T. Ayvaz, C. C. Baker, L. Begg, T. Belachew, V. Bhonagiri, M. Bihan, M. J. Blaser, T. Bloom, V. Bonazzi, J. Paul Brooks, G. A. Buck, C. J. Buhay, D. A. Busam, J. L. Campbell, S. R. Canon, B. L. Cantarel, P. S. G. Chain, I. M. A. Chen, L. Chen, S. Chhibba, 
K. Chu, D. M. Ciulla, J. C. Clemente, S. W. Clifton, S. Conlan, J. Crabtree, M. A. Cutting, N. J. Davidovics, C. C. Davis, T. Z. Desantis, C. Deal, K. D. Delehaunty, F. E. Dewhirst, E. Deych, Y. Ding, D. J. Dooling, S. P. Dugan, W. Michael Dunne, A. Scott Durkin, R. C. Edgar, R. L. Erlich, C. N. Farmer, R. M. Farrell, K. Faust, M. Feldgarden, V. M. Felix, S. Fisher, A. A. Fodor, L. J. Forney, L. Foster, V. Di Francesco, J. Friedman, D. C. Friedrich, C. C. Fronick, L. L. Fulton, H. Gao, N. Garcia, G. Giannoukos, C. Giblin, M. Y. Giovanni, J. M. Goldberg, J. Goll, A. Gonzalez, A. Griggs, S. Gujja, S. Kinder Haake, B. J. Haas, H. A. Hamilton, E. L. Harris, T. A. Hepburn, B. Herter, D. E. Hoffmann, M. E. Holder, C. Howarth, K. H. Huang, S. M. Huse, J. Izard, J. K. Jansson, H. Jiang, C. Jordan, V. Joshi, J. A. Katancik, W. A. Keitel, S. T. Kelley, C. Kells, N. B. King, D. Knights, H. H. Kong, O. Koren, S. Koren, K. C. Kota, C. L. Kovar, N. C. Kyrpides, P. S. La Rosa, S. L. Lee, K. P. Lemon, N. Lennon, C. M. Lewis, L. Lewis, R. E. Ley, K. Li, K. Liolios, B. Liu, Y. Liu, C. C. Lo, C. A. Lozupone, R. Dwayne Lunsford, T. Madden, A. A. Mahurkar, P. J. Mannon, E. R. Mardis, V. M. Markowitz, K. Mavromatis, J. M. McCorrison, D. McDonald, J. McEwen, A. L. McGuire, P. McInnes, T. Mehta, K. A. Mihindukulasuriya, J. R. Miller, P. J. Minx, I. Newsham, C. Nusbaum, M. Oglaughlin, J. Orvis, I. Pagani, K. Palaniappan, S. M. Patel, M. Pearson, J. Peterson, M. Podar, C. Pohl, K. S. Pollard, M. Pop, M. E. Priest, L. M. Proctor, X. Qin, J. Raes, J. Ravel, J. G. Reid, M. Rho, R. Rhodes, K. P. Riehle, M. C. Rivera, B. Rodriguez-Mueller, Y. H. Rogers, M. C. Ross, C. Russ, R. K. Sanka, P. Sankar, J. Fah Sathirapongsasuti, J. A. Schloss, P. D. Schloss, T. M. Schmidt, M. Scholz, L. Schriml, A. M. Schubert, N. Segata, J. A. Segre, W. D. Shannon, R. R. Sharp, T. J. Sharpton, N. Shenoy, N. U. Sheth, G. A. Simone, I. Singh, C. S. Smillie, J. D. Sobel, D. D. Sommer, P. Spicer, G. G. Sutton, S. M. Sykes, D. G. Tabbaa, M. Thiagarajan, C. M. Tomlinson, M. Torralba, T. J. Treangen, R. M. Truty, T. A. Vishnivetskaya, J. Walker, L. Wang, Z. Wang, D. V. Ward, W. Warren, M. A. Watson, C. Wellington, K. A. Wetterstrand, J. R. White, K. Wilczek-Boney, Y. Wu, K. M. Wylie, T. Wylie, C. Yandava, L. Ye, Y. Ye, S. Yooseph, B. P. Youmans, L. Zhang, Y. Zhou, Y. Zhu, L. Zoloth, J. D. Zucker, B. W. Birren, R. A. Gibbs, S. K. Highlander, B. A. Methé, K. E. Nelson, J. F. Petrosino, G. M. Weinstock, R. K. Wilson, and O. White. 2012. Structure, function and diversity of the healthy human microbiome. Nature 486:207-214.

Jacquin, J., J. Cheng, C. Odobel, C. Pandin, P. Conan, M. Pujo-Pay, V. Barbe, A. L. Meistertzheim, and J. F. Ghiglione. 2019. Microbial ecotoxicology of marine plastic debris: A review on colonization and biodegradation by the "plastisphere." Frontiers in Microbiology 10:1-16.

Jiang, W., K. Lin, D. Haver, S. Qin, G. Ayre, F. Spurlock, and J. Gan. 2010. Washoff potential of urban use insecticides on concrete surfaces. Environmental Toxicology and Chemistry 29:1203-1208.

Jin, Y., L. Lu, W. Tu, T. Luo, and Z. Fu. 2019. Impacts of polystyrene microplastic on the gut barrier, microbiota and metabolism of mice. Science of the Total Environment 649:308-317.

Jin, Y., J. Xia, Z. Pan, J. Yang, W. Wang, and Z. Fu. 2018. Polystyrene microplastics induce microbiota dysbiosis and inflammation in the gut of adult zebrafish. Environmental Pollution 235:322-329.

Joly Condette, C., V. Bach, C. Mayeur, J. Gay-Quéheillard, and H. Khorsi-Cauet. 2015. Chlorpyrifos Exposure during Perinatal Period Affects Intestinal Microbiota Associated with Delay of Maturation of Digestive Tract in Rats. Journal of Pediatric Gastroenterology and Nutrition 61:30-40. 
Kembel, S. W., P. D. Cowan, M. R. Helmus, W. K. Cornwell, H. Morlon, D. D. Ackerly, S. P. Blomberg, and C. O. Webb. 2010. Picante: R tools for integrating phylogenies and ecology. Bioinformatics 26:1463-1464.

Kim, S. D., K. S. Park, and M. B. Gu. 2002. Toxicity of hexavalent chromium to Daphnia magna: Influence of reduction reaction by ferrous iron. Journal of Hazardous Materials 93:155-164.

Kohl, K. D., E. T. Sadowska, A. M. Rudolf, M. D. Dearing, and P. Koteja. 2016. Experimental Evolution on a Wild Mammal Species Results in Modifications of Gut Microbial Communities. Frontiers in Microbiology 7:1-10.

Kunce, W., S. Josefsson, J. Örberg, and F. Johansson. 2015. Combination effects of pyrethroids and neonicotinoids on development and survival of Chironomus riparius. Ecotoxicology and Environmental Safety 122:426-431.

Kurelec, B. 1992. The multixenobiotic resistance mechanism in aquatic organisms. Critical Reviews in Toxicology 22:23-43.

Lemire, J. A., J. J. Harrison, and R. J. Turner. 2013. Antimicrobial activity of metals: Mechanisms, molecular targets and applications. Nature Reviews Microbiology 11:371-384.

Lenth, R. V., P. Buerkner, M. Herve, J. Love, H. Riebl, and H. Singmann. 2020. emmeans: Estimated Marginal Means, aka Least-Squares Means. R package version 1.4.6.

Liu, P., X. Zhan, X. Wu, J. Li, H. Wang, and S. Gao. 2020. Effect of weathering on environmental behavior of microplastics: Properties, sorption and potential risks. Chemosphere 242:125193.

Lu, L., Z. Wan, T. Luo, Z. Fu, and Y. Jin. 2018. Polystyrene microplastics induce gut microbiota dysbiosis and hepatic lipid metabolism disorder in mice. Science of the Total Environment 631-632:449-458.

Ma, Y., A. Huang, S. Cao, F. Sun, L. Wang, H. Guo, and R. Ji. 2016. Effects of nanoplastics and microplastics on toxicity, bioaccumulation, and environmental fate of phenanthrene in fresh water. Environmental Pollution 219:166-173.

Marchesi, J. R., D. H. Adams, F. Fava, G. D. a Hermes, G. M. Hirschfield, G. Hold, M. N. Quraishi, J. Kinross, H. Smidt, K. M. Tuohy, L. V Thomas, E. G. Zoetendal, and A. Hart. 2015. The gut microbiota and host health: a new clinical frontier. Gut :1-10.

Maynard, C. L., C. O. Elson, R. D. Hatton, and C. T. Weaver. 2012. Reciprocal interactions of the intestinal microbiota and immune system. Nature 489:23141.

McCormick, A., T. J. Hoellein, S. A. Mason, J. Schluep, and J. J. Kelly. 2014. Microplastic is an abundant and distinct microbial habitat in an urban river. Environmental Science and Technology 48:11863-11871.

McFall-Ngai, M., M. G. Hadfield, T. C. G. Bosch, H. V Carey, T. Domazet-Lošo, A. E. Douglas, N. Dubilier, G. Eberl, T. Fukami, S. F. Gilbert, U. Hentschel, N. King, S. Kjelleberg, A. H. Knoll, N. Kremer, S. K. Mazmanian, J. L. Metcalf, K. Nealson, N. E. Pierce, J. F. Rawls, A. Reid, E. G. Ruby, M. Rumpho, J. G. Sanders, D. Tautz, and J. J. Wernegreen. 2013. Animals in a bacterial world, a new imperative for the life sciencesh. Proceedings of the National Academy of Sciences 110:3229-3236.

Menéndez-Pedriza, A., and L. Jaumot. 2020. Microplastics : A Critical Review of Sorption Factors ,. Toxics 8:1-40.

Mestres, R., and G. Mestres. 1992. Deltamethrin: Uses and Environmental Safety. Page Springer-Verlag.

Moran, N. A., and D. B. Sloan. 2015. The Hologenome Concept: Helpful or Hollow? PLoS Biology 13:1-10. 
Mousavi, S. A., and F. Khodadoost. 2019. Effects of detergents on natural ecosystems and wastewater treatment processes: a review. Environmental Science and Pollution Research 26:26439-26448.

Nasuti, C., M. M. Coman, R. A. Olek, D. Fiorini, M. C. Verdenelli, C. Cecchini, S. Silvi, D. Fedeli, and R. Gabbianelli. 2016. Changes on fecal microbiota in rats exposed to permethrin during postnatal development. Environmental Science and Pollution Research 23:10930-10937.

Nicholson, J. K., E. Holmes, J. Kinross, R. Burcelin, G. Gibson, W. Jia, and S. Pettersson. 2012. Host-Gut Microbiota Metabolic Interactions. Science 108:1262-1268.

Nyman, A., D. Huyben, T. Lundh, and J. Dicksved. 2017. Effects of microbe- and mussel-based diets on the gut microbiota in Arctic charr (Salvelinus alpinus). Aquaculture Reports 5:34-40.

Paradis, E., and K. Schliep. 2019. Ape 5.0: An environment for modern phylogenetics and evolutionary analyses in R. Bioinformatics 35:526-528.

Pérez-Candela, M., J. M. Martín-Martínez, and R. Torregrosa-Maciá. 1995. Chromium(VI) removal with activated carbons. Water Research 29:2174-2180.

Pietroiusti, A., A. Magrini, and L. Campagnolo. 2015. New frontiers in nanotoxicology: Gut microbiota / microbiome-mediated effects of engineered nanomaterials. Toxicology and Applied Pharmacology:8-13.

Qiao, R., Y. Deng, S. Zhang, M. B. Wolosker, Q. Zhu, H. Ren, and Y. Zhang. 2019. Accumulation of different shapes of microplastics initiates intestinal injury and gut microbiota dysbiosis in the gut of zebrafish. Chemosphere 236:124334.

$\mathrm{R}$ Core Team. 2020. A language and environment for statistical computing. $\mathrm{R}$ Foundation for Statistical Computing, Vienna, Austria.

Rasmussen, J. J., U. Nørum, M. R. Jerris, P. Wiberg-Larsen, E. A. Kristensen, and N. Friberg. 2013. Pesticide impacts on predator-prey interactions across two levels of organisation. Aquatic Toxicology 140-141:340-345.

Richardson, L. A. 2017. Evolving as a holobiont. PLOS Biology 15:e2002168.

Rist, S., A. Baun, and N. B. Hartmann. 2017. Ingestion of micro- and nanoplastics in Daphnia magna - Quantification of body burdens and assessment of feeding rates and reproduction. Environmental Pollution 228:398-407.

Rochman, C. M., B. T. Hentschel, and S. J. Teh. 2014. Long-Term Sorption of Metals Is Similar among Plastic Types: Implications for Plastic Debris in Aquatic Environments 9.

Rodrigues, A. C. M., C. Gravato, C. Quintaneiro, C. Barata, A. M. V. M. Soares, and J. L. T. Pestana. 2015. Sub-lethal toxicity of environmentally relevant concentrations of esfenvalerate to Chironomus riparius. Environmental Pollution 207:273-279.

Roger, F., S. Bertilsson, S. Langenheder, O. A. Osman, and L. Gamfeldt. 2016. Effects of multiple dimensions of bacterial diversity on functioning, stability and multifunctionality. Ecology 97:2716-2728.

Rosenberg, E., and I. Zilber-Rosenberg. 2014. The Hologenome Concept: Human, Animal and Plant Microbiota.

Semova, I., J. D. Carten, J. Stombaugh, L. C. Mackey, R. Knight, S. A. Farber, and J. F. Rawls. 2013. Microbiota regulate intestinal absorption and metabolism of fatty acids in the zebrafish 12:277-288.

Seung Chul, S., K. Sung Hee, Y. Hyejin, K. Boram, K. Aeri C, L. Kyung Ah, Y. Joo Heon, and L. Won Jae. 2011. Drosophila Microbiome Modulates Host Developmental and Metabolic Homeostasis via Insulin Signaling. Science 334:670-674. 
Sharpton, T. J. 2018. Role of the Gut Microbiome in Vertebrate Evolution. mSystems 3:e00174-17.

Sibley, P. K., and M. L. Hanson. 2011. Ecological Impacts of Organic Chemicals on Freshwater Ecosystems. Ecological Impacts of Toxic Chemicals (Open Access):138-164.

Skjolding, L. M., S. N. Sørensen, N. B. Hartmann, R. Hjorth, S. F. Hansen, and A. Baun. 2016. Aquatic Ecotoxicity Testing of Nanoparticles-The Quest To Disclose Nanoparticle Effects. Angewandte Chemie 128:15448-15464.

Sobrino-Figueroa, A. 2018. Toxic effect of commercial detergents on organisms from different trophic levels. Environmental Science and Pollution Research 25:13283-13291.

Sommer, F., and F. Bäckhed. 2013. The gut microbiota - masters of host development and physiology. Nature Publishing Group 11:227-238.

Souza, R. S., F. Virginio, T. I. S. Riback, L. Suesdek, J. B. Barufi, and F. A. Genta. 2019. Microorganism-based larval diets affect mosquito development, size and nutritional reserves in the yellow fever mosquito aedes aegypti (Diptera: Culicidae). Frontiers in Physiology 10.

Stilling, R. M., T. G. Dinan, and J. F. Cryan. 2014. Microbial genes, brain \& behaviour-epigenetic regulation of the gut-brain axis. Genes, Brain and Behavior 13:69-86.

Tanaka, K., H. Takada, R. Yamashita, K. Mizukawa, and M. Fukuwaka. 2013. Accumulation of plastic-derived chemicals in tissues of seabirds ingesting marine plastics. Marine Pollution Bulletin 69:219-222.

Tchounwou, P. B., C. G. Yedjou, A. K. Patlolla, and D. J. Sutton. 2012. Molecular, clinical and environmental toxicicology Volume 3: Environmental Toxicology. Molecular, Clinical and Environmental Toxicology 101:133-164.

Toshio, N. 1992. Nerve membrane Na+ channels as targets of insecticides. Trends in Pharmacological Sciences 13:236-241.

Tremaroli, V., and F. Bäckhed. 2012. Functional interactions between the gut microbiota and host metabolism. Nature 489:242-249.

Vargas, J. E., and J. Dussán. 2016. Adsorption of Toxic Metals and Control of Mosquitos- borne Disease by Lysinibacillus sphaericus: Dual Benefits for Health and Environment. Biomed Environ Sci 29:187-196.

Vavrek, M. J. 2011. fossil: Palaeoecological and palaeogeographical analysis tools. Palaeontologia Electronica 14.

Wagner, M., and S. Lambert. 2018. Freshwater Microplastics. Page Freshwater Microplastics The Handbook of Environmental Chemistry.

Wang, J., J. Peng, Z. Tan, Y. Gao, Z. Zhan, Q. Chen, and L. Cai. 2016. Microplastics in the surface sediments from the Beijing River littoral zone: composition, abundance, surface textures and interaction with heavy metals. Chemosphere 171:248-258.

Wasielewski, H., J. Alcock, and A. Aktipis. 2016. Resource conflict and cooperation between human host and gut microbiota: implications for nutrition and health. Annals of the New York Academy of Sciences 1372:20-28.

Weston, D. P., H. L. Ramil, and M. J. Lydy. 2013. Pyrethroid insecticides in municipal wastewater. Environmental Toxicology and Chemistry 32:2460 2468.

Yuan, X., Z. Pan, C. Jin, Y. Ni, Z. Fu, and Y. Jin. 2019. Gut microbiota: An underestimated and unintended recipient for pesticide-induced toxicity. Chemosphere 227:425-434. 
Zeng, X., X. Xu, H. M. Boezen, and X. Huo. 2016. Children with health impairments by heavy metals in an e-waste recycling area. Chemosphere 148:408-415.

Zettler, E. R., T. J. Mincer, and L. A. Amaral-Zettler. 2013. Life in the "plastisphere": Microbial communities on plastic marine debris. Environmental Science and Technology 47:7137-7146.

Zha, Y., A. Eiler, F. Johansson, and R. Svanbäck. 2018. Effects of predation stress and food ration on perch gut microbiota. Microbiome 6:1-12.

Zhou, J., N. Du, D. Li, J. Qin, H. Li, and G. Chen. 2021. Combined effects of perchlorate and hexavalent chromium on the survival, growth and reproduction of Daphnia carinata. Science of the Total Environment 769:144676.

Zhu, D., Q. L. Chen, X. L. An, X. R. Yang, P. Christie, X. Ke, L. H. Wu, and Y. G. Zhu. 2018. Exposure of soil collembolans to microplastics perturbs their gut microbiota and alters their isotopic composition. Soil Biology and Biochemistry 116:302-310. 


\section{Acta Universitatis Upsaliensis}

Digital Comprehensive Summaries of Uppsala Dissertations from the Faculty of Science and Technology 2050

Editor: The Dean of the Faculty of Science and Technology

A doctoral dissertation from the Faculty of Science and Technology, Uppsala University, is usually a summary of a number of papers. A few copies of the complete dissertation are kept at major Swedish research libraries, while the summary alone is distributed internationally through the series Digital Comprehensive Summaries of Uppsala Dissertations from the Faculty of Science and Technology. (Prior to January, 2005, the series was published under the title "Comprehensive Summaries of Uppsala Dissertations from the Faculty of Science and Technology".) 